\title{
Metrology applied to Human Ecology: critical analysis of geospatial data for regionalization of Brazilian Anthromes
}

\author{
Maximiliano Soares Lemos Araujo Gobbo ( $\square$ maxgobbo91@gmail.com ) \\ Instituto Nacional de Metrologia Qualidade e Tecnologia https://orcid.org/0000-0002-4668-2364 \\ Thiago de Oliveira Araujo \\ Instituto Nacional de Metrologia Qualidade e Tecnologia \\ Claudia de Oliveira Faria Salema \\ Instituto Nacional de Metrologia Qualidade e Tecnologia
}

\section{Research Article}

Keywords: metrology, socio-ecological system, critical analysis, anthromes, ISO/IEC 17025, land use planning

Posted Date: September 24th, 2021

DOI: https://doi.org/10.21203/rs.3.rs-833533/v1

License: (c) (i) This work is licensed under a Creative Commons Attribution 4.0 International License. Read Full License 


\section{Abstract}

Establishing territorial planning tools that meet the precepts of sustainable development is always challenging. In this sense, anthromes emerge as a differential mechanism. Its structure considers population and environmental parameters, which optimizes the recognition of areas of interest in the territory. However, it is necessary to consider regional aspects, approaching the input data in the cluster analysis. Assuming this, data on population density and land use and cover of National Spatial Data Infrastructure (INDE - Brazil) were analyzed as a source for regionalization. Therefore, an analytical system based on the ISO/IEC 17025 standard was proposed. Globally, this standard is used to guarantee the quality of results through the metrological pillars. Thus, the validation parameters were used to assess the adequacy of the methods to the intended uses and the ability to bring the data closer to the local reality. The tools to guarantee the validity of internal results guided the verification of the quality of treatments performed on the results generated by the methods. The results show that the methods meet their respective scopes, framing the geospatial information investigated in the acceptance profile required for the regionalization of Brazilian anthromes. Furthermore, they bring the information closer to the local reality and characterize important natural features. In this way, the quality of the geospatial data indexed in the INDE to be applied in the cluster analysis was guaranteed. Furthermore, a resource that collaborates in the critical analysis of the results and in the evaluation of environmental and anthropic methods was presented.

\section{Introduction}

In a constantly changing world, ecosystem changes are increasingly present (Ellis, 2015; Ellis et al., 2010; Morrison et al., 2021; Mottl et al., 2021; Nowosad et al., 2019). Globally, government entities, non-governmental organizations, research groups and academic centers are dedicated to understanding how ecosystem changes affect the climate, environment, and geology of the planet in the Anthropocene (Brondizio et al., 2016; Crona et al., 2021; Delanty, 2018; Keck, 2021; Louro et al., 2021; Rockström et al., 2009; Ryder et al., 2021). In this context, it is imperative to plan, systematize and adapt the use of spaces and natural resources to ensure a healthy environment for present and future generations (Loft et al., 2017; Loiseau et al., 2021; Magliocca et al., 2015; Matthews, 2021; Mbaru et al., 2021; Parreira et al., 2019; Picuno et al., 2019; Somorin et al., 2014), as advocated by the Sustainable Development Goals (UN, 2015).

Entering the ecosystem sustainability framework, the literature suggests that socio-ecological models (Balvanera et al., 2017; Costanza \& Kubiszewski, 2012; Danielsen et al., 2021; Martínez et al., 2013) significantly collaborate to maintain planetary resilience and of life on Earth (Bagstad et al., 2013a; Burkhard et al., 2012; Groot et al., 2010; Haines-Young et al., 2012; Maes et al., 2012). Through them, the relationship established between humanity and the environment is better understood. In addition, they can assist in the development of public policies for spatial planning and planning at the national level (Bagstad et al., 2013b; Battiston et al., 2021; Costenbader, 2011; O'Connor et al., 2021; Petrescu et al., 2021).

Anthromes (Ellis \& Ramankutty, 2008), subdivisions of terrestrial biomes based on the interpolation between man and the environment, emerge as a tool that can contribute to this scope. The modeling of this system is done by associating information on population density and land use and land cover (Ellis, 2015; Ellis et al., 2012). Data are transformed into numerical values, statistically treated, and applied to correlation analysis (Alessa \& Chapin, 2008; Ellis, 2013b; Ellis \& Ramankutty, 2008). This mathematical resource aggregates the data, considering its coverage area and the respective geolocations (Ellis, 2011; Ellis et al., 2010).

In the mapping produced by Ellis and Ramankutty (2008) the data were captured on global geospatial platforms. The generated product portrays anthropogenic biomes on a global scale and can be viewed through Google LCC's Earth platform. after downloading the plug-in available to the user (http://www.ecotope.org/anthromes/maps/). On a global scale, this technological resource makes it possible to understand the relationships between population and environment in each of the classified anthropogenic biomes (Ellis, 2015; Jia et al., 2019; Nowosad et al., 2019). It also allows its application at the regional level (countries and continents) as a mechanism for the management of natural resources and for the development of public and environmental policies (De Keersmaeker et al., 2014; Picuno et al., 2019) (Fig. 1). 
However, viewing details at a local scale (municipalities and states) points to the limitation of the product (Fig. 2). In polygons of smaller areas there are discrepancies between the real information and the information presented in the mapping. One of the reasons that lead to this deviation is found in the large areas represented by data from global platforms, which makes detailing into smaller areas unfeasible and consequently impairs the mapping of anthromes (De Keersmaeker et al., 2014; Loiseau et al., 2021; Pedersen et al., 2021; Saah et al., 2020).

The literature points out that national databases can provide more consistent sources of geographic information for mapping anthromes (Danielsen et al., 2021; Junior, 2021; Li et al., 2016; Picuno et al., 2019). These platforms have a greater number of data for smaller areas, which enables greater detailing of the investigated sectors (Chuai \& Feng, 2019; Massetti \& Gil, 2020; Parente et al., 2019; Winkler et al., 2021; Zheng et al., 2014). Consequently, by applying these data in the correlation analysis, it would be possible to increase the detail of the mapping of Brazilian anthropogenic biomes (Dandois et al., 2017; Dandois et al., 2015b; Ellis, 2014b; Magliocca et al., 2015 ; Margulies et al., 2016; Morrison et al., 2021), including data that consider the natural features of the country (Dandois \& Ellis, 2013; Dandois et al., 2015a; Fuentealba et al., 2021; Magliocca \& Ellis, 2013; Zahawi et al., 2015) to collaborate with the development of spatial planning and planning policies.

When it comes to regional bases for providing geographic information closer to the local reality, Brazil has the National Spatial Data Infrastructure (INDE) (BRASIL, 2008). Its creation aims to harmonize national geographic information structures with other Spatial Data Infrastructures (IDEs) around the globe (CINDE, 2010). One of the central objectives is the comparability of results between national IDEs, to create a global scheme for decision-making and to produce more assertive public policies (IBGE, 2019). It is also noted that the IDEs intend to generate traceability to geographic information and give reliability to the data reported therein (CINDE, 2010; CONCAR, 2017).

An important resource regarding the structure of the INDE is the methodological standardization to produce geographic information (CINDE, 2010). Standard methods, or official methods, were conceived by institutions that legally produce geospatial data (official INDE actors) and are adopted to systematize the production of results in the country (BRASIL, 2008; IBGE, 2019). Another tool presented by the INDE structure is the Metadata Profile (CONCAR, 2017), based on the ISO 19115 Standard (ISO, 2003), where the minimum data requirements for indexing in the INDE platform are pointed out. Metadata provide information about the method, the producers, the treatments performed on the data and additional information that support the results (CONCAR, 2017; ISO, 2003). This unique presentation scheme allows the comparison of data between nations (Magliocca et al., 2014; Steffen et al., 2015) and enables critical analysis (Goldbergs et al., 2018; Ryder et al., 2021) of the results based on metrological tools (BIPM, 2017).

In this context, Metrology adds to Human Ecology by presenting tools that support the quality assurance of results (Brondizio et al., 2016; Steffen et al., 2015), either to assess reliability geospatial information through structures that attest to the operability of the methods and the results they generate (Mahmoud et al., 2021; Mittaz et al., 2019), or to propose schemes for data comparability and traceability through associated characteristics the measurement or estimation performed (BIPM, 2017; Fermam, 2012; Sené et al., 2017). In general terms, the ISO/IEC 17025(ISO, 2017) standard designates two metrological resources that contribute to this scope. Method validation parameters (item 7.2.2) can help demonstrate the suitability for the intended use of standard methods in measuring or estimating geographic information (De Bievre et al., 1998; Macarthur \& von Holst, 2012; Magnusson, 2014; Thompson et al., 2002), as population density and land use and cover. Moreover, the tools to guarantee the validity of internal results (item 7.7.1.) provide resources for critical analysis of the results (ISO, 2015b, 2015c, $2016,2019)$, helping in the evaluation and evidence of the resources used before, during and after the production of results (Bagstad et al., 2013b; Balvanera et al., 2017; IPCC, 2014, 2018; Maestripieri et al., 2017; Mas et al., 2012).

The evaluation of the methods and results they generate through these metrological tools can help to reduce distortions between the real image and the mapped image (Burkhard et al., 2012; DeFries et al., 2012; Goldbergs et al., 2018; Pouliot et al., 2014). By analyzing the methods considering the validation parameters, it is possible to identify whether the methods can reduce the areas of representation (Chuai \& Feng, 2019; Jia et al., 2019; Parente et al., 2019), to generate better visualization of details in the terrain. It is imperative that the methods of population density and land use and cover represent smaller areas of polygons (Didoné et al., 2017; Leinenkugel et al., 2013; Olsson et al., 2019), for that the correlation analysis generates a more 
accurate mapping of the anthromes (Ellis, 2015; Ellis \& Ramankutty, 2008; Magliocca \& Ellis, 2013). On that account, by demonstrating that the standard methods of INDE (CINDE, 2010) can improve the baseline information applied in the correlation analysis (Erb et al., 2017; Haines-Young et al., 2012; Wang \& Han, 2019), it would be possible to regionalize Brazilian anthromes to adopt them as a tool for spatial planning at a local scale (city/state) (Magliocca et al., 2015; Margulies et al., 2016).

Even, the literature points out that the uncertainty of geospatial data applied in the cluster analysis must be addressed (Costa, 2017; Freire \& Castro, 2014). Therefore, the tools to guarantee the validity of internal results $($ ISO, 2017) help to identify the treatments performed, inferring the efficiency of these treatments, and pointing to mechanisms that help to guarantee the quality of the information to be used in the cluster analysis (Blundo et al., 2021; Loiseau et al., 2021; van Wilgen, 2021). In addition, these tools help identify reliability mechanisms as imperative to increase the quality of mapped information (Brewer et al., 2019; Mahmoud et al., 2021; Sené et al., 2017).

Therefore, this study verified the presence of method validation parameters and tools to ensure the validity of internal results (ISO, 2017) in the standard methods of the INDE and in the results generated by them (CINDE, 2010; BRAZIL, 2008; CONCAR, 2017). The objective was to correlate these two metrological tools (ISO, 2017) to methods of population density (IBGE, 2010, 2013b, 2018b) and land use and cover (IBGE, 2013a, 2017, 2018a, 2020a), in a way to establish a critical analysis scheme to ensure the quality of results on the national platform (IBGE, 2019b). By establishing this scheme, it is expected to contribute with other users of geospatial data, indicating to a guideline for a better understanding of the methods and results generated by them. In addition, it was verified through this systematic if the methods can improve the resolution of geographic information (Araujo et al., 2017), to adjust the mapping of anthromes to the local reality. It is indicated that this research recommends the application of data from the INDE platform in the analysis of cluster for the regionalization of Brazilian anthromes as a resource for land use planning and planning.

\section{Methodology}

The starting point for the regionalization of Brazilian anthromes is the National Spatial Data Infrastructure (INDE). In the document "INDE Implementation Plan" (CINDE, 2010), the Brazilian Institute of Geography and Statistics (IBGE) is described as the actor responsible for the production and management of data on population density (IBGE, 2013b) and land cover and use (IBGE, 2013a). Based on this, all documents dealing with the two methods were listed: manuals and technical reports, data and metadata, mappings and tables. Table 1 describes all the investigated documents, divided between methods and results. 
Investigated documents.

\section{Methods and Documents \\ Results}

Demographic • INSTITUTO BRASILEIRO DE GEOGRAFIA E ESTATÍSTICA (IBGE); Manuais técnicos em Geociências

Census número 14: acesso e uso de dados geoespaciais. Rio de Janeiro, IBGE, 143 p., 2019.

(method)

- INSTITUTO BRASILEIRO DE GEOGRAFIA E ESTATÍSTICA (IBGE); Metodologia do censo demográfico 2010. IBGE, Rio de Janeiro, 712p., 2013.

- INSTITUTO BRASILEIRO DE GEOGRAFIA E ESTATÍ́STICA; Estimativas da População Residente para os Municípios e para as Unidades da Federação Brasileiros com Data de Referência em $1^{\circ}$ de julho de 2019. Ministério da Economia e Instituto Brasileiro de Geografia e Estatística (IBGE), 2019.

\section{Demographic Census} (results)

• http://www.metadados.geo.ibge.gov.br/geonetwork_ibge/srv/por/main.home

• https://sidra.ibge.gov.br/tabela/1298

- https://sidra.ibge.gov.br/tabela/1288

- https://sidra.ibge.gov.br/tabela/608

• https://sidra.ibge.gov.br/tabela/1286

- https://sidra.ibge.gov.br/tabela/1294

- https://sidra.ibge.gov.br/tabela/1309

• https://sidra.ibge.gov.br/tabela/3107

• https://sidra.ibge.gov.br/tabela/1301

Land Use and Cover (methods)
- COMISSÃO NACIONAL DE CARTOGRAFIA (CONCAR); Norma Cartográfica Brasileira: Especificações Técnicas para Estruturação de Dados Geoespaciais Vetoriais (ET-EDGV 3.0). Ministério do Planejamento, Desenvolvimento e Gestão/CONCAR, Brasília, 43p., 2017.

- IBGE. Manuais técnicos em Geociências número 14: acesso e uso de dados geoespaciais. Rio de Janeiro, IBGE, 143 p., 2019.

- INSTITUTO BRASILEIRO DE GEOGRAFIA E ESTATÍSTICA (IBGE); Avaliação da qualidade de dados geoespaciais: manual técnico em Geociências nº 13. IBGE, Rio de Janeiro, 2ª ed., 117p., 2019.

- INSTITUTO BRASILEIRO DE GEOGRAFIA E ESTATístICA (IBGE); Manuais Técnicos em Geociência (n. 7): manual técnico de uso da terra. IBGE, Rio de Janeiro, $3^{\text {a }}$ ed., 171 p., 2013.

- INSTITUTO BRASILEIRO DE GEOGRAFIA E ESTATÍSTICA (IBGE); Manuais Técnicos em Geociências (n.1): manual técnico da vegetação brasileira. IBGE, Rio de Janeiro, $2^{\mathrm{a}}$ ed., 271 p., 2012.

- INSTITUTO BRASILEIRO DE GEOGRAFIA E ESTATÍSTICA (IBGE); Manuais Técnicos em Geociências (n.12): manual de procedimentos técnicos para fiscalização, controle de qualidade e validação da base cartográfica contínua na escala 1:250000. IBGE, Rio de Janeiro, 31 p., 2011.

- INSTITUTO BRASILEIRO DE GEOGRAFIA E ESTATísTICA (IBGE); Mapeamento de Uso e Cobertura da Terra Utilizando dados numéricos do Censo Agropecuário 2006: nota técnica. IBGE, Rio de Janeiro, 4 p., 2018.

- INSTITUTO BRASILEIRO DE GEOGRAFIA E ESTATÍ́STICA (IBGE); Monitoramento da Cobertura e Uso da Terra do Brasil 2000-2010 - 2012-2014 em grade territorial estatística. IBGE, Rio de Janeiro, 35p., 2017.

- INSTITUTO BRASILEIRO DE GEOGRAFIA E ESTATÍSTICA (IBGE); Monitoramento da Cobertura e Uso da Terra do Brasil 2014-2016. IBGE, Rio de Janeiro, 32p., 2018.

- INSTITUTO BRASILEIRO DE GEOGRAFIA E ESTATÍSTICA (IBGE); Monitoramento da Cobertura e Uso da Terra do Brasil 2016-2018. IBGE, Rio de Janeiro, 27p., 2020. 


\section{Methods and Documents \\ Results}

Land Use and Cover (results)
- https://www.ibge.gov.br/geociencias/informacoes-ambientais/cobertura-e-uso-da-terra.html

• http://www.metadados.inde.gov.br/geonetwork/srv/por/main.home

- http://mapasinterativos.ibge.gov.br/recortes/index.html

• http://mapasinterativos.ibge.gov.br/atlas_ge/brasil1por1.html

- https://bdiaweb.ibge.gov.br/\#/home

- https://www.ibge.gov.br/apps/macrocaracterizacao/

• http://mapasinterativos.ibge.gov.br/monitoramento_uso/

• http://www.metadados.inde.gov.br/geonetwork/srv/por/main.home

- http://www.metadados.inde.gov.br/geonetwork/srv/por/metadata.show?id=75659\&currTab=simple

- https://www.ibge.gov.br/geociencias/informacoes-ambientais/vegetacao/15842-biomas.html?=\&t=oque-e

• http://metadados.geo.ibge.gov.br/geonetwork_ibge/srv/por/main.home

- https://www.ibge.gov.br/geociencias/informacoes-ambientais/cobertura-e-uso-da-terra/15833-uso-daterra.html?=\&t=o-que-e

- https://www.ibge.gov.br/geociencias/informacoes-ambientais/vegetacao/24252-macrocaracterizacaodos-recursos-naturais-do-brasil.html?=\&t=o-que-e

- https://www.ibge.gov.br/geociencias/informacoes-sobre-posicionamento-geodesico/servicos-paraposicionamento-geodesico/16312-progrid.html?=\&t=o-que-e

- https://www.ibge.gov.br/geociencias/informacoes-ambientais/vegetacao/22453-cartas-1-250-000.html? $=\& \mathrm{t}=$ acesso-ao-produto

- https://www.ibge.gov.br/geociencias/informacoes-ambientais/vegetacao/10872-vegetacao.html?=\&t=oque-e

• https://www.ibge.gov.br/geociencias/informacoes-ambientais/vegetacao/22460-vegetacao-porestado.html?=\&t=o-que-e

Source: the author.

After listing all documents, the metrological concepts present in the ISO/IEC 17025 (ISO, 2017) were transposed to adapt it to the investigated methods. In general, this standard is used as a resource for evaluating the competence of calibration and testing laboratories. Despite this designation, its scope concerns the evaluation of methods and the results they generate, allowing its application in other areas of science. It is pointed to that the standard in question synthetically designates the validation parameters of methods and the tools to guarantee the validity of internal results. Furthermore, it does not describe direct application to the "population density" and "land use and cover" methods. Therefore, based on the literature, a correlation was made between the metrological concepts of each of the method validation parameters and the tools to guarantee the validity of results and the characteristics of the investigated methods. In Table 2 the correlations between the validation parameters of methods and the two methods are presented, while in Table 3 the tools to guarantee the validity of internal results are treated. 
Table 2

Correlation between Metrological Concepts of Method Validation and Characteristics of Environmental and Anthropogenic Methods.

Correlation between Metrological Concepts of Method Validation and Characteristics of Environmental and Anthropogenic Methods.

$\begin{array}{lll}\text { Validation } & \text { Metrological Definition of } \\ \text { Parameter } & \text { the Validation Parameter } & \begin{array}{l}\text { Correlation of the metrological } \\ \text { concept with characteristics of the } \\ \text { demographic method }\end{array}\end{array}$

Specificity Ability of the method to generate a signal only for the product of interest. Specific characteristic of the
population.

$\begin{array}{ll}\text { Selectivity } & \text { Ability of the method to } \\ \text { generate responses for } \\ \text { different components of } \\ \text { interest, but which are } \\ \text { distinguishable from each } \\ \text { other. }\end{array}$

Working Range Used to demonstrate that the results produced by the method are provided with acceptable precision and accuracy in the range in which it is operated.

Different characteristics in the investigated population that can be individualized.

\section{Correlation of the metrological concept with characteristics of "land use and cover" methods}

Terrain-specific feature during image classification and processing.

Characteristics that typify the different uses in the field during image classification and processing.
Ability of the method to produce geographic information within the standard of acceptance of results, which is established in synergy between the institution responsible for the standard method and the reference institutions.

Ability to describe trait(s) in different population sizes.
Ability of the method to produce geographic information within the standard of acceptance of results, which is established in synergy between the institution responsible for the standard method and the reference institutions.

Ability to describe terrain feature(s) in different sizes of areas. range, it refers to the method's ability to produce linear responses within the investigated operating range.

\section{Detection limit It refers to the smallest amount of information identified in a particular investigated sector, but that cannot be quantified for the acceptance standards established for the methods.}

Quantification
Limit

Less amount of information needed to identify a certain characteristic in the investigated sector.

\section{Accuracy (Recovery + Precision > Precision $=$ Repeatability + Intermediate Precision + Reproducibility)}

\section{Recovery}

\begin{abstract}
Ability of the method to produce results close to real values (true values).
\end{abstract}

\begin{abstract}
Minimum number of individuals censused to obtain population information, with confidence established for the method.
\end{abstract}

Minimum number of individuals to be censused to obtain information on the population, according to the area of operation.
Area smaller than that which the classification and processing method can distinguish, generating confusion in the classification produced.
Ability of the method to estimate a given characteristic of the census population against the real value of the characteristic.
Smaller area than the classification and processing method can operate and produce results in the acceptance range proposed by the data producer.

Delimitation of a certain land use/cover against the true value of the area.
Comparison of the average of the results generated by the method to a reference value (trend analysis bias), normally carried out by Certified Reference Materials (CRMs).
Comparison with other demographic operations, using growth rates for estimation.
Use of standard classification images to analyze the method's ability to distinguish features in terrains.

Source: the author. 
Correlation between Metrological Concepts of Method Validation and Characteristics of Environmental and Anthropogenic Methods.

\begin{tabular}{|c|c|c|c|}
\hline Repeatability & $\begin{array}{l}\text { Degree of agreement } \\
\text { between results obtained by } \\
\text { the same method in the } \\
\text { same area, with a short } \\
\text { space between } \\
\text { measurements/estimations, } \\
\text { being performed by the } \\
\text { same operator. }\end{array}$ & $\begin{array}{l}\text { Sequential tests performed before } \\
\text { the census operation. }\end{array}$ & $\begin{array}{l}\text { Analysis of the same image over } \\
\text { and over to verify that the } \\
\text { processing and classification } \\
\text { software responds to the } \\
\text { minimum precision value } \\
\text { established for the procedure. }\end{array}$ \\
\hline $\begin{array}{l}\text { Intermediate } \\
\text { Precision }\end{array}$ & $\begin{array}{l}\text { Degree of agreement } \\
\text { between the results, varying } \\
\text { pre-established } \\
\text { characteristics during the } \\
\text { information } \\
\text { measurement/estimation } \\
\text { process. }\end{array}$ & $\begin{array}{l}\text { Variation of census takers and the } \\
\text { census time interval as sources of } \\
\text { variation in the census method. }\end{array}$ & $\begin{array}{l}\text { Analysis of orbital images } \\
\text { captured throughout the year and } \\
\text { the different imaging sources used } \\
\text { to calibrate the method. }\end{array}$ \\
\hline Reproducibility & $\begin{array}{l}\text { Degree of agreement } \\
\text { between results for the } \\
\text { same scope, varying } \\
\text { operators, and } \\
\text { areas/sectors. }\end{array}$ & $\begin{array}{l}\text { Degree of agreement between the } \\
\text { results obtained by the different } \\
\text { census takers and in the different } \\
\text { census sectors, to cover the entire } \\
\text { population. }\end{array}$ & $\begin{array}{l}\text { Degree of agreement between the } \\
\text { classification carried out in the } \\
\text { different areas investigated in the } \\
\text { territory. }\end{array}$ \\
\hline $\begin{array}{l}\text { Adequacy to } \\
\text { Mathematical } \\
\text { Models }\end{array}$ & $\begin{array}{l}\text { Possibility of establishing a } \\
\text { mathematical model to } \\
\text { methods response. }\end{array}$ & $\begin{array}{l}\text { Estimation model represents a } \\
\text { mathematical model, which is } \\
\text { based on calculated population } \\
\text { growth rates. }\end{array}$ & $\begin{array}{l}\text { Processing and classification } \\
\text { method represents a } \\
\text { mathematical model, considering } \\
\text { its response to different false-color } \\
\text { scales in bands } 5 \mathrm{R}, 4 \mathrm{G} \text { and } 3 \mathrm{~B} \text {, } \\
\text { which are numerically expressed } \\
\text { in the analyses. }\end{array}$ \\
\hline
\end{tabular}

Source: the author. 
Table 3

Correlation between Metrological Concepts of Tools to Guarantee the Validity of Internal Results and Characteristics of

Environmental and Anthropogenic Methods.

Correlation between Metrological Concepts of Tools to Guarantee the Validity of Internal Results and Characteristics of Environmental and Anthropogenic Methods.

$\begin{array}{ll}\text { Tool to } & \text { Metrological } \\ \text { Guarantee the } & \text { definition of the Tool } \\ \text { Validity of } & \text { for } \\ \text { Internal Results } & \end{array}$

Correlation of the metrological
concept with characteristics of
"demographic density" methods

Correlation of the metrological concept with characteristics of "land use and cover" methods

\section{Guarantee of Validity of Internal Results}

\begin{tabular}{ll}
$\begin{array}{l}\text { Use of } \\
\text { reference } \\
\text { materials or } \\
\text { materials for } \\
\text { quality control }\end{array}$ & $\begin{array}{l}\text { Use of established } \\
\text { standards for the } \\
\text { methods as a } \\
\text { resource to analyze } \\
\text { the quality of the } \\
\text { information produced. }\end{array}$ \\
$\begin{array}{l}\text { Using } \\
\begin{array}{l}\text { alternative } \\
\text { calibrated } \\
\text { instrumentation } \\
\text { to provide } \\
\text { traceable } \\
\text { results }\end{array}\end{array} \quad \begin{array}{l}\text { Instruments used in } \\
\text { conjunction with } \\
\text { methods to generate } \\
\text { traceable and } \\
\text { comparable results } \\
\text { with other institutions. }\end{array}$ \\
\hline
\end{tabular}

\begin{tabular}{|c|c|}
\hline $\begin{array}{l}\text { Functional } \\
\text { checks of } \\
\text { measuring and } \\
\text { testing } \\
\text { equipment }\end{array}$ & $\begin{array}{l}\text { Temporal analysis of } \\
\text { the instruments used } \\
\text { in the methods, } \\
\text { evaluating their ability } \\
\text { to produce results } \\
\text { within acceptance } \\
\text { standards. }\end{array}$ \\
\hline
\end{tabular}

Use of population growth rates calculated based on previous census operations and which are used to assess the quality of results obtained in the present census operation.

Use of statistical resources to estimate the population, as well as other tools that help to compare national and international demographic results.
Use of standard images as a resource to assess the quality of processing and classification of orbital images, which resemble reference materials for quality control.

Use of other imaging sources to analyze the capacity of the classification software to operate within the acceptance range established in the method.
Systems used in the census operation, enabling operators to verify problems during the operation and analyze compliance with acceptance standards.
Resources for monitoring the processing and classification of land use and cover assist in checking the software throughout the entire procedure.

$\begin{array}{ll}\begin{array}{l}\text { Use of check } \\ \text { patterns or }\end{array} & \text { Mechanisms used to } \\ \text { check the instruments } \\ \text { work patterns } & \text { used by the methods, } \\ \text { with control } & \text { as well as the results } \\ \text { charts, when } & \text { they produce. } \\ \text { applicable } & \end{array}$

Use of check patterns or with control applicable

Intermediate checks on measuring equipment
This tool reflects actions taken during the execution of the methods, resulting in the minimum standard for acceptance of the result.

Replicated tests
or calibrations,
using the same
or different
methods

Tests performed on methods to produce results and demonstrate the adequacy of the resources used to generate them.
Operation monitoring systems are examples of checking patterns, pointing out information through the census indicators and about the census process.
Use of standard images in processing software as an aid to product quality control. Use of standardization in the reporting of generated results, serving as a control chart for the generated geographic information.

Evaluation of the classification of the result to the minimum standard for acceptance of the generated classification.
Indicators as tools for the intermediate checks of the census, as they are intricately linked to the questionnaires applied in the census operation.
Carrying out actions

Retest or recalibration of retained items to reassess the results obtained by the methods.
Tests performed prior to the application of the demographic method are mechanisms to calibrate the method, to generate results that fall within the scope of the action.
Tests performed using standard images are resources that aid in the calibration of processing and calibration, as the results must match the stipulated acceptance level.
Performing the reapplication of the questionnaire (sampling) in households where the information was not properly collected or not collected is a mechanism to retest the retained item.
Field validation or reclassification of uses and cover performed.

Source: the author. 


\begin{tabular}{|c|c|c|c|}
\hline \multicolumn{4}{|c|}{$\begin{array}{l}\text { Correlation between Metrological Concepts of Tools to Guarantee the Validity of Internal Results and Characteristics of } \\
\text { Environmental and Anthropogenic Methods. }\end{array}$} \\
\hline $\begin{array}{l}\text { Correlation of } \\
\text { Results from } \\
\text { Different } \\
\text { Characteristics } \\
\text { of an Item }\end{array}$ & $\begin{array}{l}\text { Interpolation of } \\
\text { different } \\
\text { characteristics of the } \\
\text { same investigated } \\
\text { object. }\end{array}$ & $\begin{array}{l}\text { The questionnaires applied must } \\
\text { have different characteristics on the } \\
\text { census population. }\end{array}$ & $\begin{array}{l}\text { Different terrain properties, which } \\
\text { lead to different classifications. }\end{array}$ \\
\hline $\begin{array}{l}\text { Critical analysis } \\
\text { of reported } \\
\text { results }\end{array}$ & $\begin{array}{l}\text { Study performed on } \\
\text { the results produced } \\
\text { by the methods, to } \\
\text { validate them or not. }\end{array}$ & $\begin{array}{l}\text { Evaluation of census indicators } \\
\text { during operation. After the operation, } \\
\text { the comparative analysis of the } \\
\text { results obtained with those estimated } \\
\text { (which use the growth rates } \\
\text { calculated through other census } \\
\text { operations). }\end{array}$ & $\begin{array}{l}\text { Used when rating in software through } \\
\text { acceptance level. After classification, } \\
\text { the field work intends to validate the } \\
\text { results generated, enabling the } \\
\text { production of the field report. }\end{array}$ \\
\hline $\begin{array}{l}\text { Intralaboratory } \\
\text { Comparisons }\end{array}$ & $\begin{array}{l}\text { Comparison of results } \\
\text { obtained by the result } \\
\text { producer. }\end{array}$ & $\begin{array}{l}\text { In addition, comparison with data } \\
\text { obtained from other census } \\
\text { operations. }\end{array}$ & $\begin{array}{l}\text { Comparison between different areas } \\
\text { and their results, based on the } \\
\text { established acceptance level. }\end{array}$ \\
\hline $\begin{array}{l}\text { Testing of blind } \\
\text { sample(s) }\end{array}$ & $\begin{array}{l}\text { Tests performed } \\
\text { using unknown data. }\end{array}$ & $\begin{array}{l}\text { Lack of knowledge of the population } \\
\text { before the census to determine a } \\
\text { given demographic characteristic. }\end{array}$ & $\begin{array}{l}\text { Lack of knowledge of land use and } \\
\text { cover in the orbital image applied in } \\
\text { the processing and classification } \\
\text { software, given that no previous } \\
\text { treatment was applied to the images. }\end{array}$ \\
\hline
\end{tabular}

After establishing this correlation, the documents listed in Table 1 were searched for notes or characteristics that would raise the presence of these metrological tools in both methodological structures. In addition, the presence of ancillary resources that also contributed to guarantee the quality of environmental and anthropic results was verified.

\section{Results}

First, it is not pointed out in the methodological framework of the standard methods of INDE for population density and land use and cover (IBGE, 2013a, 2013b) direct employment of the ISO/IEC 17025 (ISO, 2017). However, in the structuring and functioning of both methods, studies and verifications that are directly correlated to those proposed by the metrological tools applied here are described. Therefore, the results presented are the result of the transposition of metrological concepts into the methods of "demographic density" (IBGE, 2013b) and "land use and cover" (IBGE, 2013a) (Tables 2 and 3).

The survey carried out in the Technical Manuals and Reports (Table 1) enabled the identification of characteristics that describe the presence of the validation parameters (7.2.2.) (ISO), 2017) in both methods. Table 4 summarizes the parameters that were found in the methodological structures. 
Table 4

Verification of the presence of the method validation parameters (7.2.2. $)^{74}$ in the technical manuals of the methods of land use and cover ${ }^{105}$ and demographic density 101 of INDE.

\begin{tabular}{|lll|}
\hline Verification of the presence of the method validation parameters (7.2.2.) \\
\hline Validation parameters & Method: Land Use and Cover & Method: Demographic Census \\
\hline Selectivity & $\mathrm{X}$ & $\mathrm{X}$ \\
\hline Specificity & $\mathrm{X}$ & $\mathrm{X}$ \\
\hline Linearity & $\mathrm{X}$ & $\mathrm{X}$ \\
\hline Working Range & $\mathrm{X}$ & $\mathrm{X}$ \\
\hline Detection Limit & $\mathrm{X}$ & $\mathrm{X}$ \\
\hline Quantification Limit & $\mathrm{X}$ & $\mathrm{X}$ \\
\hline Accuracy & $\mathrm{X}$ & $\mathrm{X}$ \\
\hline Recovery & $\mathrm{X}$ & $\mathrm{X}$ \\
\hline Repeatability & $\mathrm{X}$ & $\mathrm{X}$ \\
\hline Intermediate Precision & $\mathrm{X}$ & $\mathrm{X}$ \\
\hline Reproducibility & $\mathrm{X}$ & $\mathrm{X}$ \\
\hline Adequacy To Mathematical Models & $\mathrm{X}$ & $\mathrm{X}$ \\
\hline Source: the author. & & \\
\hline
\end{tabular}

On the other hand, the investigation of data, metadata, numerical results, and mappings allowed the detection of resources that raised the tools to guarantee the validity of internal results (7.7.1.) (ISO, 2017) in both methods. Table 5 depicts the tools that are present in the treatment and analysis of the results produced by the methods. 
Table 5

Verification of the presence of tools to guarantee the validity of internal results (7.7.1. $)^{74}$ in technical reports, data, and metadata of the land use and cover ${ }^{105}$ and demographic density 101 methods of INDE.

Verification of the presence of tools to guarantee the validity of internal results (7.7.1.) ${ }^{74}$

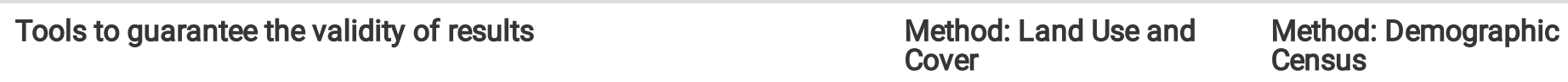

Use of reference materials or materials for quality control

Using alternative calibrated instrumentation to provide traceable $\quad x \quad X$ results

\begin{tabular}{llll}
\hline Functional checks of measuring and testing equipment & $X$ & $X$ \\
$\begin{array}{l}\text { Use of check patterns or work patterns with control charts, when } \\
\text { applicable }\end{array}$ & $X$ & $X$
\end{tabular}

\begin{tabular}{llll}
\hline Intermediate checks on measuring equipment & $X$ & $X$ \\
\hline $\begin{array}{l}\text { Replicated tests or calibrations, using the same or different } \\
\text { methods }\end{array}$ & $X$ & $X$
\end{tabular}

Retest or recalibration of retained items $\quad X \quad X$

\begin{tabular}{lll} 
Correlation of Results from Different Characteristics of an Item & $X$ & $X$ \\
\hline Critical analysis of reported results & $X$ & $X$ \\
\hline Intralaboratory comparisons & $X$ & $X$ \\
\hline Testing of blind sample(s) & $X$ & $X$ \\
\hline
\end{tabular}

Source: the author.

Complementarily, the set of researched documents evidenced some accessory tools of the methods, which contribute to guarantee the quality of the results generated by them. These tools are described in Table 6 and are significant for understanding how the methods work.

Table 6

Accessory tools to guarantee the quality of results.

\begin{tabular}{|c|c|}
\hline METHOD & ACCESSORY TOOLS TO GUARANTEE THE QUALITY OF RESULTS \\
\hline $\begin{array}{l}\text { DEMOGRAPHIC } \\
\text { DENSITY } \\
\text { METHOD }\end{array}$ & $\begin{array}{l}\text { 1) ISO } 19115 \text { standard. 2) Management System of the Collection Post (SIGPC). 3) Management System } \\
\text { of the Collection Post (SIGC). 4) Imputation and Criticism System. 5) System Validation and Approval } \\
\text { System. 6) Territorial Base. 7) Geographic Operational Base (BOG). 8) GEOBASE. 9) Quality Inspector. } \\
\text { 10) Estimation Error Analysis in the Mathematical Model. 11) Survey to Evaluate the Coverage of the } \\
2010 \text { Census Collection (PA 2010). 12) Pairing of } 2010 \text { Census and } 2010 \text { PA Data. 13) Method } \\
\text { Calibration. 14) Estimates Calculations. 15) Sample Error. 16) Sample fractions. }\end{array}$ \\
\hline $\begin{array}{l}\text { METHOD OF } \\
\text { LAND USE AND } \\
\text { COVER }^{105}\end{array}$ & $\begin{array}{l}\text { 1) Use of the series of ISO } 19115 \text { standards to report data. 2) Comparison of analytical results with } \\
\text { results from other information bases. 3) Methods for evaluating and measuring errors = data interpreter } \\
\text { and sample checking. 5) Estimates with equivalent precision. 6) Sample fraction based on the } \\
\text { dimensions of the areas to be reassessed. }\end{array}$ \\
\hline
\end{tabular}

Source: the author.

This set of information enabled the critical analysis of the methods and their respective results. It also brought notes on the reliability, comparability and traceability of geographic information indexed on the INDE platform. In addition, it made it possible to verify the method's ability to reduce the coverage areas of geospatial data indexed in INDE. These points set the stage for the discussion that follows. 


\section{Discussion}

The investigation fulfilled demonstrated that the standard methods of "demographic density" (IBGE, 2013b) and "land use and cover" (IBGE, 2013a) of the National Spatial Data Infrastructure (INDE) (CINDE, 2010) do not use of Standard 17025 (ISO, 2017$)$ in the methodological framework or during the production and analysis of results. However, the research showed that a significant part of the metrological tools for validating methods (7.2.2.) and ensuring the validity of internal results (7.7.1.) is analyzed in the planning, structuring, execution and quality control of methods and their results (IBGE, 2013a, 2013b), to contribute to the pillars of reliability, comparability, and traceability of geographic information (IBGE, 2019b).

\section{Method validation parameters}

\section{Selectivity and Specificity}

these two validation parameters are associated with the ability of the census method (IBGE, 2013b) to select characteristics of interest. Specificity $(I S O, 2017)$ refers to the collection of specific information from the set of population characteristics (Magnusson, 2014), such as age, gender, ethnicity. While selectivity (ISO, 2017) is linked to different characteristics that generate signals, but which can be distinguished, that is, analyzed separately (Macarthur \& von Holst, 2012). Assuming these parallels, the analysis revealed that features of these parameters make up the standard INDE method (IBGE, 2013b), which significantly contribute to the characterization of populations (Magnusson, 2014). To regionalize the anthromes is important have results that represent the population in different population agglomerates, to characterize them in the best possible way (Ellis, 2014a; Magliocca et al., 2014; Schug et al., 2018). In this manner, these two aspects of validation significantly contribute to the use of these data in the correlation analysis (Erb et al., 2017; Haines-Young et al., 2012), as they demonstrate the ability of the standard method to distinguish information relevant to the construction of the anthromes model (Ellis, 2011; ELLIS, 2013; Ellis \& Ramankutty, 2008).

In the land use and cover method (IBGE, 2013a), the specificity (ISO, 2017) refers to the method's ability to identify a unique terrain feature during the processing and classification of orbital images (Meng et al., 2017). In addition, selectivity (ISO, 2017) deals with the method's ability to assimilate different types of use and coverage, enabling the individualization of characteristics in small areas (Bayoudh et al., 2015). This research verified that in the standard method (IBGE, 2013a) a reference value is used for the acceptance of the classification generated in the processing and classification (Lark et al., 2017; Liu et al., 2018). This value, also treated as "minimum acceptance accuracy", is based on the method's ability to distinguish areas through false color in bands 5R, 4G and 3B (Leinenkugel et al., 2013). It was possible to recognize that the establishment of this value is commonly used for this scope in the literature (Amici, 2011; Rial et al., 2017; Saah et al., 2020). In Brazil, the minimum acceptance accuracy level is $85 \%$ and is similar to international acceptance profiles for other methods (Chetcuti et al., 2021; Koch et al., 2021; Mishra et al., 2021; Morrison et al., 2021; Tao et al., 2021; Winkler et al., 2021; Yletyinen et al., 2021). For Metrology, the reference value (VIM, 2012) provides evidence on the measurement capacity of institutions (BIPM, 2017) and, through it, it is possible to establish traceability to the International Bureau (Araujo et al., 2017). In this line of thought, by establishing a reference value for the acceptance of processing and classification of orbital images in land use and land cover methods, it would be possible to establish resources for comparability (VIM, 2012) of the information nationally (Mittaz et al., 2019). Furthermore, through it, it would be feasible to establish traceability (VIM, 2012) schemes of the geographic information produced by other institutions (Sené et al., 2017). In this sense, the verification of the two parameters (ISO, 2017) in the structuring of the method (IBGE, 2013a) provides evidence that points to the efficiency of the software in identifying and distinguishing properties in the field (Girardin et al., 2021; Jia et al., 2019; Parreira et al., 2019). By verifying these parameters in the standard method, it was also found that the method can distinguish particularities on the ground in areas of $1 \mathrm{~km}^{2}$ within the acceptance accuracy level (IBGE, 2013a). This area is sufficient to distinguish important natural features in the territory (De Keersmaeker et al., 2014; Li et al., 2016; Liu et al., 2018; Maestripieri et al., 2017; Pouliot et al., 2014) and provides subsidies that favor the application of data in the cluster analysis for regionalization of anthromes (Ellis, 2011; Ellis, 2015).

\section{Working Range and Linearity}


these parameters are associated with the ability of census methods (IBGE, 2013b) to operate in a working range (ISO, 2017), generating results with acceptable precision and accuracy for the intended use (Magnusson, 2014). The investigation in the census method demonstrated that the design of sample fractions over the years aims to obtain sufficient data to characterize the population in each census sector (IBGE, 2011, 2018b, 2020b). Therefore, the reference values of the sample fractions guide the number of individuals to be censused to meet the linear model proposed by the method (Spalding \& Hull, 2021; Zheng et al., 2014). The literature indicates that concise data on the different population densities in an area contributes to the identification of singularities of anthromes at a local scale (Ellis et al., 2010; Magliocca et al., 2014; Olsson et al., 2019). In this way, through these methodological aspects, paths are indicated for the regionalization of anthromes, to assimilate characteristics and natural features existing in the national territory (Ellis, 2014a; Magliocca et al., 2013, 2014).

Additively, in the land cover and use method (IBGE, 2013a) the working range (ISO, 2017) refers to the range established between the limits of largest and smallest area that the classification software can operate, framing the product in the acceptance profile (Laraby \& Schott, 2018; Macarthur \& von Holst, 2012). Completely, linearity (ISO, 2017) is associated with this range, presenting a linear response to the variation in sector sizes and characterizing them with the referred precision (Do Valle Júnior et al., 2019; Magnusson, 2014). Through this research, quadrants of $1 \mathrm{~km}^{2}$ were identified as the smallest classification area of the standard method, within the acceptance value (IBGE, 2013a). This size favors the assimilation of characteristics specific to the territory, such as natural features linked to rivers and preservation and conservation areas (Calvin et al., 2019; Koch et al., 2021; Magioli, et al., 2021b; Morrison et al., 2021; Schug et al., 2018; Winkler et al., 2021). By determining a single area size for investigation, the results produced for the entire national territory become comparable (Magliocca et al., 2015; Sené et al., 2017), reaching one of the pillars that are aimed at comparability (VIM, 2012). Furthermore, by assimilating errors and uncertainties (VIM, 2012) in image processing (level of precision), it is possible to have more clarity about the information generated (BIPM, 2008), improving the geospatial data and ensuring its quality based on the reference value (Laraby \& Schott, 2018; Thompson et al., 2002). In this sense, the richness of geographic information indexed in the INDE favors the application of land use and cover data (IBGE, 2013a) in the cluster analysis for regionalization of anthromes (Ellis, 2011; Ellis, 2015; Zheng et al., 2014).

\section{Detection Limit and Quantification Limit}

both parameters are linked to the minimum amount of information for the census method to respond (Magnusson, 2014), in the other words, for the method to be able to present results that characterize the population. Following this metrological precept, its close relationship with the establishment of sample fractions in census methods is noted (IBGE, 2010, 2013b, $2020 \mathrm{~b})$. The fractions reflect the concept that a minimum number of collections is necessary for the estimation to be accomplished with the precision aimed at (Arlé et al., 2021; Dong et al., 2021; Magliocca et al., 2014; Song et al., 2021; al., 2012). If the number is lower than necessary, the method will generate noise (Macarthur \& von Holst, 2012), but it will not be possible to characterize the information (Igbal \& Khan, 2021; Schug et al., 2018; Trappes, 2021). For geographic information to be sufficiently close to the reality of the census sector, it is imperative to establish more accurate sample fractions (Liu et al., 2018; Saah et al., 2020; Sené et al., 2017). In this manner, through the analysis of the sample fractions of the demographic method, it was possible to verify that the population is efficiently described in each of the census sectors (IBGE, 2013b, 2020b), bringing the population data closer to smaller areas when compared to the bases global (Blundo et al., 2021; Erb et al., 2017; Li et al., 2016; Nedkov \& Burkhard, 2012). This directly contributes to the spatialization of information about the population (Umunay, 2015; Margulies et al., 2016; Rockström et al., 2009), allowing a closer approximation of the demographic data to the local reality (Danielsen et al., 2021; Junior, 2021; Mbaru et al., 2021; Picuno et al., 2019).

In the land use and cover method (IBGE, 2013a), the quantification limit (ISO, 2017) deals with the smallest area that the processing and classification software can distinguish, producing results within the acceptance profile (Magnusson, 2014). Smaller than this sector size, the program does not perform the operation efficiently, generating noise (Macarthur \& von Holst, 2012), which characterizes the detection limit (ISO, 2017). These limits, in the standard INDE method, are established by the method's ability to distinguish disparate tones in the false-color scale in the $5 R, 4 G$ and 3B bands, as previously presented (IBGE, 2013a). The delimitation of a minimum size of area promotes the comparability of geographic information, as it provides characteristics on the readability of the method in different contexts of land cover and use (Liu et al., 2018; Magioli et 
al., 2021b; Morrison, 2021; Winkler et al., 2021). In addition, noise analysis contributes to the study of uncertainties associated with the classification and mapping generated (Goldbergs et al., 2018; Parreira et al., 2019). Assuming the analysis of these two validation parameters in the structuring of the standard method, it was observed that both help to ensure the quality of the data generated, as it is through them that it is identified that the method can reduce the areas of analysis without harming the results generated (Chuai \& Feng, 2019; Umunay, 2015; Parente et al., 2019; Vuolo et al., 2015). Therefore, the challenge of improving the resolution of anthromes in the national territory finds other resources that collaborate to meet this objective (Alessa \& Chapin, 2008; Ellis, 2011; Ellis, 2015).

\section{Recovery}

the study of this parameter reflects the trend analysis (Hegerl et al., 2010; Magliocca et al., 2015), usually associated with population estimation (IBGE, 2018b, 2019a). This research found that the trend analysis is based on population growth rates, which are calculated based on the historical series of operations (IBGE, 2013b, 2018b). The comparison between the estimated value (present base) and the projected value (past base) directly helps in controlling the quality of the information generated (Macarthur \& von Holst, 2012). Through it, it becomes possible to study the statistical variability between the two pieces of information (Thompson et al., 2002). This brings consistency to the population data, positively affecting the regionalization of anthromes (Magliocca et al., 2015), as it delivers more robust demographic information (Ellis, 2013a; Jia et al., 2019).

In the land use and cover method (IBGE, 2013a) this parameter is associated with the use of standard images to assess the ability of the classification method to distinguish terrain properties (Do Valle Júnior et al., 2019). There is in the standard method the use of previously classified images, which are established as standard by their framing in the acceptance profile (IBGE, 2012, 2013a). Its application is aimed at trend analysis (bias) (Macarthur \& von Holst, 2012), which is linked to the agreement of the results obtained over consecutive measurements. The analysis of the method trend contributes to reducing the uncertainty of the generated products, in view of the distortion between the results obtained that should be presented in this aspect (Laraby \& Schott, 2018; Meng et al., 2017). Additively, the analysis of this parameter contributes to the adequacy of the method to the intended use, in other words, it demonstrates its ability to maintain a pattern of measurements with small variations in the results generated (Bayoudh et al., 2015; Feilhauer \& Schmidtlein, 2011; Magnusson, 2014). In this sense, it was noted that this practice is already consolidated in the standard method of the INDE, which generates reliability in geographic information on land use and cover (Sené et al., 2017). Furthermore, the reporting of deviations from the results generated by repeated measurements minimizes the impacts of errors and uncertainties (BIPM, 2008) on the products generated, contributing to ensure the quality of information for cluster analysis (Goldbergs et al., 2018; Parreira et al., 2019). Consequently, there is other evidence that corroborates the use of data from the INDE platform as a basis for regionalization of Brazilian anthromes (Ellis, 2011; Ellis, 2015; Ellis \& Ramankutty, 2008).

\section{Intermediate Precision}

reflects the degree of agreement between the results generated by the same method when varying characteristics during the process (Magnusson, 2014). Through research using the standard method (IBGE, 2013b) it was noted that this parameter is linked to different values of standard deviation and coefficients of variation (Macarthur \& von Holst, 2012), which change according to size of the population of the census sector (IBGE, 2011, 2018b, 2019a). The two statistical resources contribute to the demonstration of method accuracy (Thompson et al., 2002), increasing the quality of information (Mairota et al., 2013; Mastrandrea et al., 2010; Nunes et al., 2021) and allowing the verification of the proximity of the data to the local scale (Gaüzère \& Devictor, 2021; Plowright et al., 2017). In addition, both collaborate to control errors and uncertainties (VIM, 2012) in the estimations, as they are part of the study of measurement uncertainty (BIPM, 2008). In this sense, the analysis of this parameter has more cohesive data (Arlé et al., 2021; Boer et al., 2021; Morrison, 2021), contributing to obtain better results in the cluster analysis (Mittaz et al., 2019; Sun et al., 2017) for the regionalization of Brazilian anthromes (Ellis, 2015).

In the method of land use and cover (IBGE, 2013a), the parameter encompasses the degree of agreement between the classifications of the same image, varying the period of image capture and the source of the image of the same area (Valle Júnior et al., 2019; Laraby \& Schott, 2018). The investigation of this validation parameter strongly contributes to temporal

Page 15/39 
analyzes in socio-ecological systems (Landrum et al., 2015; Meng et al., 2017). The variability of results over a given period positively affects the understanding of environmental dynamics (Chen et al., 2021; Parente et al., 2019; Winkler et al., 2021; Yang et al., 2019) and, consequently, that of the mapping of anthromes (Amiot et al., 2021; Dong et al., 2021; Finlayson et al., 2021; Jia et al., 2019). Research accomplished using the standard method (IBGE, 2013a) indicated that measurements are demonstrated in a pre-established period, to optimize the understanding of changes in land use and land cover (IBGE, 2017, 2018a, 2020a). This is essential to apply anthromes mapping as a land use planning tool, as it assumes territorial transformations over the years (De Keersmaeker et al., 2014; O'Connor et al., 2021; Picuno et al., 2019; Wang \& Han, 2019; Weissteiner et al., 2011; Zheng et al., 2014). Therefore, the analysis of the method's intermediate precision is a unique resource for solving the barriers associated with temporal analyzes (Amiot et al., 2021; Pouliot et al., 2014; Qin et al., 2021).

\section{Accuracy}

This parameter is a metrological composition based on recovery and intermediate precision aspects (Magnusson, 2014; Thompson et al., 2002). In the investigation fulfilled using the census method, it was observed that there is no variation in the different levels of information aggregation (cities, states and country) (IBGE, 2011, 2013b, 2019b; Pinto et al., 2020), which may be verified through the consulted tables shown in Table 1. Thus, the accuracy of the information in different census sectors contributes to the application of these data in the cluster analysis (Magliocca et al., 2014; Olsson et al., 2019). This is because the data make it possible to approximate the model to smaller areas (Gaüzère \& Devictor, 2021; Lark et al., 2017; Sené et al., 2017; Zheng et al., 2014), considering important regional cuts, which it is essential for the regionalization of anthromes (Calvin et al., 2019; Chuai \& Feng, 2019; Magliocca et al., 2015). In addition, the data allow the joining of areas for models that encompass different characteristics of the sectors (Altieri et al., 2014; Sun et al., 2017).

When it comes to the land use and cover method (IBGE, 2013a), accuracy assumes the character of the method's ability to classify a certain land use and cover against its true classification (Magnusson, 2014). In this sense, it is noted that the investigation of the other parameters that compose it lead to the interpretation of the accuracy with which the software operates, considering the level of precision for acceptance of the result (Bayoudh et al., 2015; Do Valle Júnior et al., 2019; Laraby \& Schott, 2018). Accuracy demonstrates the effectiveness of the software in classifying land properties, assimilating important natural features for the application of anthromes in land use planning (Liu et al., 2018; Novelli et al., 2016). In addition, it is correlated with quality control (Sené et al., 2017; Thompson et al., 2002) and supplements the process of producing data closer to reality (Landrum et al., 2015; Parente et al., 2019; Plowright et al., 2017; Wen et al., 2019), carrying characteristics that better describe the areas analyzed. Through research made in the standard method (IBGE, 2013a) it was possible to identify that the parameter applies to the structuring of the method, as it sufficiently describes areas of $1 \mathrm{~km}^{2}$. In this way, the data indexed in the INDE enriches the knowledge about the areas (Arlé et al., 2021; Blundo et al., 2021; Boer et al., 2021; Morrison, 2021), approximating the information of the local area through the complex expressed by accuracy, consequently improving the results that can be obtained in the cluster analysis (Mittaz et al., 2019; Sun et al., al., 2017).

\section{Repeatability}

associated with the degree of agreement between results obtained by the same method in the same area, with a short space between the estimates, being performed by the same operator (Magnusson, 2014). In verifying the census method, it was found that the series of tests performed during the structuring of the method has its results analyzed by a single system (IBGE, 2013b). Testing contributes substantially to demonstrating the quality of information, as it allows the assessment of the variation in the measurement/estimation results produced (Magliocca \& Ellis, 2013; Thum et al., 2021). In this way, data variability, which directly affects the regionalization of anthromes, is minimized and becomes capable of being controlled (Alvarenga et al., 2016; Landrum et al., 2015; Pouliot et al., 2014; Schug et al., 2018; Sené et al., 2017; Vuolo et al., 2015), since it is known how concordant the values obtained for each census sector area.

Regarding the method of land use and cover (IBGE, 2013a), the parameter refers to the analysis of the same orbital image numerous times during a pre-established time interval, to verify whether the results are variants among themselves (Laraby \& Schott, 2018; Macarthur \& von Holst, 2012). In the research fulfilled, it was noted that this mechanism is used to evaluate 
software associated with the standard method and serve as a tool for quality control (IBGE, 2013a, 2017, 2018a, 2020a; Pinto et al., 2020). This testing is usual and aims to generate cohesive results during the investigation period (Bayoudh et al., 2015; Feilhauer \& Schmidtlein, 2011). The analysis of this parameter in the standard method offers means for the reliability (VIM, 2012) of the information, as the synergy between the results demonstrates that the method is efficient in meeting its objective (Meng et al., 2017; Sené et al., 2017). As a result, repeatability (ISO, 2017) provides signs of the method's conformity to its scope, ensuring cohesive results at the national level (Magnusson, 2014; Thompson et al., 2002), which linearly meets the requirements of variability of information in each area (Alvarenga et al., 2016; Landrum et al., 2015; Schug et al., 2018). Thus, this validation parameter grants substantiality to the data listed in the INDE, ensuring the quality aimed at applying them in the correlation analysis (Haines-Young et al., 2012; Wang \& Han, 2019).

\section{Reproducibility}

refers to comparing the mean of the results generated by the method to a reference value (trend analysis) when varying aspects of the operation (De Bievre et al., 1998; Magnusson, 2014). In the demographic case, this verification is based on previous census operations, as confirmed by the investigation made using the standard method (IBGE, 2013b). It is also noted the variation of aspects, such as enumerators and collection areas, which narrows its relationship with reproducibility (ISO, 2017). According to the Technical Manual (IBGE, 2013b), it was observed that the results generated in different areas are compared to the respective previous results obtained in the same areas. This is a common feature to confirm that the method produces concordant data by varying characteristics in its application (Landrum et al., 2015; Schug et al., 2018; Vuolo et al., 2015) and is postulated as an indispensable tool in Metrology (Brewer et al., 2019; Mahmoud et al., 2021; Mittaz et al., 2019; Sené et al., 2017). Consequently, the methodological standardization established within the scope of INDE (CINDE, 2010), accompanied by the control of information with variants, contributes to the unification of the source of demographic data for the regionalization of anthromes on a national scale (Morrison et al., 2021; Nowosad et al., 2019), as it considers important factors concerning the cluster analysis (Erb et al., 2017; Haines-Young et al., 2012; Wang \& Han, 2019).

About the method of land use and cover (IBGE, 2013a), this parameter covers the analysis of the degree of agreement between the classifications generated in different areas, considering the acceptance profile as the basis (Bayoudh et al., 2015; Magnusson, 2014). The degree of agreement is also added when the source of orbital images for processing and classification of sectors is varied (Dandois et al., 2017; Dandois et al., 2015b; Leinenkugel et al., 2013; Okujeni et al., 2018). According to the investigation accomplished in the standard method, there are regions where it is necessary to use other imaging sources (IBGE, 2011, 2016, 2019b); however, the product generated must fit the same acceptance profile (IBGE, 2012, 2013a). Comparability (VIM, 2012) of products generated in different areas and/or by different imaging sources is of great value to analyze the efficiency of the software (Laraby \& Schott, 2018; Novelli et al., 2016; Parente et al., 2019; Schug et al., 2018). In addition, these comparative resources are good indicators of the quality of the information generated, because through them it is possible to identify limitations in the software that allow the method to be improved (Battiston et al., 2021; Caldararu et al., 2021; Hou et al., 2021; Jia et al., 2019; Wang \& Ellis, 2005). For this reason, the attention given to this parameter helps in the evaluation of the resources that support the classification of land uses and land cover, enabling the assimilation of characteristics of the method that attest to the reliability (VIM, 2012) of the geographic information (Amici, 2011; Lark et al., 2017; Liu et al., 2018; Pouliot et al., 2014). In this way, the reproducibility analysis(ISO, 2017) in the standard method of the INDE provides evidence on the efficiency of the method in analyzing and identifying different land cover and uses (Macarthur \& von Holst, 2012;), improving knowledge of the areas (Chuai \& Feng, 2019; Dandois \& Ellis, 2013; Massetti \& Gil, 2020; Plowright et al., 2017; Sené et al., 2017; Winkler et al., 2021 ; Zheng et al., 2014), which is essential for the regionalization of anthromes.

\section{Adequacy to Mathematical Models}

this parameter is associated with the possibility of establishing a mathematical model for the results that the method produces (Magnusson, 2014). In this sense, it was observed that the population projection model is built based on a mathematical model (IBGE, 2018b, 2019a). According to the projection model (IBGE, 2018b), the basis for the calculation is made with reference to previous years of census operations and intuit to reduce the uncertainty in the generated estimate (IBGE, 2011, 2013b, 2019a). Since it is possible to identify the uncertainty (VIM, 2012) associated with the population projection (IBGE, 2018b, 2019a), it is

Page $17 / 39$ 
feasible to control the uncertainty of the regional model of anthromes when using these data (Goldbergs et al., 2018). In this way, there is an indication of how divergent the model is from the reality of the research sector (Magliocca et al., 2014; Olsson et al., 2019), which favors its application as a land use planning tool (Chetcuti et al., 2021; O'Connor et al., 2021; Picuno et al., 2019; Zheng et al., 2014).

In the land use and cover method (IBGE, 2013a), the parameter involves the ability to establish a mathematical (algorithmic) structure that supports the functioning of the processing and classification software (Macarthur \& von Holst, 2012; Magnusson, 2014). As indicated by this research, the response to different false-color scales in bands $5 R, 4 G$ and $3 B$ is numerically expressed, enabling the structuring of a mathematical model for analyzing orbital images (Bayoudh et al., 2015; Laraby \& Schott, 2018; Meng et al., 2017). This model helps to improve the software, since through it is possible to verify how the responses (results) are generated for different imaging sources (Amici, 2011; Liu et al., 2018; Morrison et al. al., 2021; Novelli et al., 2016; Rial et al., 2017). This mechanism leads to a better understanding of the method and allows the survey of the most suitable imaging sources for the intended use of the method (Parreira et al., 2019). Reasoning about this aspect, the establishment of a mathematical model points to the reliability (VIM, 2012) of the information (Sené et al., 2017). Also, through it, it is possible to recognize the limitations of the method and prioritize adjustments to meet local needs, such as unidentified natural features in larger areas (Calvin et al., 2019; Magliocca et al., 2015; Olsson et al., 2019). According to the mathematical model used in the standard method (IBGE, 2013a) characteristics that substantially describe areas of $1 \mathrm{~km}^{2}$ are delimited. Furthermore, it demonstrates the efficiency of the method when considering the classification acceptance profile, which is of significant relevance for the regionalization of anthromes. Therefore, the set of information expressed by the mathematical model leads to other tools that guarantee the quality of information (Mairota et al., 2013; Mastrandrea et al., 2010), enabling comparability (VIM, 2012) between the different areas analyzed (Fuentealba et al., 2021; Li et al., 2016; Tao et al., 2021; Yang et al., 2019). Finally, this provides greater stability to the input data in the cluster analysis (Picuno et al., 2019; Roberts et al., 2021), which raises a better adequacy of the mapping of anthromes to the national reality (Chuai \& Feng, 2019; Dandois \& Ellis, 2013; Gaüzère \& Devictor, 2021; Leinenkugel et al., 2013; Parente et al., 2019; Winkler et al., 2021).

According to the points discussed above, the validation parameters (item 7.2.2.) (ISO, 2017) are resources that effectively contribute to the assessment of the suitability of the methods for the intended use (Macarthur \& von Holst, 2012; Magnusson, 2014). Although the producer does not employ the 17025 Standard (ISO, 2017), there are several indications that point to the knowledge of these metrological resources in the demographic (IBGE, 2013b) and land use and cover method (IBGE, 2013a). The analysis of the presence of these tools (ISO,2017) also brought information that led to significant improvements in the mapping of anthromes at a local scale, supporting the pillars of comparability, reliability and traceability (VIM, 2012) of geographic information. It was also shown that the method significantly approximates the geographic information of the studied area (IBGE, 2013a, 2013b), providing a unique source for the regionalization of anthromes in Brazil. In addition, the analyzes of these parameters (ISO, 2017) foster the ideals of assimilating metrological aspects in the methods, contributing to studies on uncertainty and measurement/estimation error (BIPM, 2008).

\section{Tools to Guarantee the Validity of Internal Results}

\section{Use of reference materials or materials for quality control}

the tool is closely associated with the use of metrological resources to compare the generated result with a reference value (ISO, 2017). In other words, it refers to a predetermined value that serves as a comparison parameter to control the quality of the results generated by an instrument or method of measurement or estimation (Mahmoud et al., 2021). As there is no Reference Material (RM) or Certified Reference Material (CRM) structured following ISO GUIDE 31 (ISO, 2015a) for census or environmental methods, a parallel is created here between what is used as reference value by the result producer (IBGE, 2013b) and the metrological concept presented in the Guide (ISO, 2015a). Assuming that RMs are quality control materials (Brewer et al., 2019; ISO, 2015), it is possible to correlate them with the growth rates used to project the population (IBGE, 2018b). As the values projected by the mathematical model (population projection) (IBGE, 2018b; Russo et al., 2014) serve as a reference for the values estimated by the census method (census operation) (IBGE, 2013b, 2019a), framing -if in an acceptance profile, you get other indicatives that support this equivalence. Another important point involving quality control (Sené et al., 2017;

Page 18/39 
Thompson et al., 2002) is linked to the Management System of the Collection Post (SIGPC) and the Management System of Collection Indicators (SIGC) (IBGE, 2013b). Both help control the quality of information during and after the census operation (IBGE, 2013b), indicating points for review and correction of results that do not fit the acceptance profile (ISO, 2017). Furthermore, the evidence found in this investigation showed that the use of these resources supports the critical analysis of results (Brondizio et al., 2016; Mairota et al., 2013; Steffen et al., 2015). Checking the reliability (VIM, 2012) of geospatial data through quality tools (ISO, 2017) helps the construction of socio-ecological and economic models, leading to a better understanding of reality (Danielsen et al., 2021; Morrison et al., 2021; Schaffartzik et al., 2021; Yletyinen et al., 2021; Ozkaynak et al., 2021). In this sense, the schemes presented in the population density method (IBGE, 2013b) confirm the reliability of census information produced nationally (CINDE, 2010). This leads, at the same time, to greater reliability in the regionalization of Brazilian anthromes (Ellis, 2015; Louro et al., 2021; Magliocca et al., 2014; Matthews, 2021).

On the other hand, in the land use and cover method (IBGE, 2013a) this tool is closely associated with the use of standard images to assess the quality of the processing and classification performed (Blundo et al., 2021; Mittaz et al., 2019; Winkler et al., 2021), as shown in this work. According to the description presented in the Technical Manual of the method (IBGE, 2013a), it was recognized that the standard images describe the sector in detail through measurements, studies and characteristics already identified (Burgess, 2021; Chuai \& Feng, 2019; Do Valle Júnior et al., 2019; Elez et al., 2013), even indicating the uncertainty associated with geographic information through the reference value for acceptance (Goldbergs et al., 2018). In this sense, a parallel is established between these standard images and the Reference Materials (RMs) (Brewer et al., 2019), described in ISO GUIDE 31 as resources for quality control (ISO, 2015a). These images strongly help the result producer to control the quality of the generated geographic information (Roberts et al., 2021; Thompson et al., 2002), as they make it possible to assess whether the method is adjusted and if it provides answers that fit within the minimum precision that is intended (Brondizio et al., 2016; Mairota et al., 2013; Ryder et al., 2021; Tao et al., 2021). Furthermore, by establishing the standard for acceptance of results, the quality of the products generated for different types of land use and cover is synchronized (Lark et al., 2017; Rodríguez-Rodríguez et al., 2021; Saah et al., 2020). In this regard, this research identified that the INDE standard method employs standard images to control and guarantee the quality of processing performed for different contexts of areas (IBGE, 2013a). Consequently, the method provides synergistic geographic information for the entire national sphere, which optimizes the results obtained in the correlation analysis (Olsson et al., 2019). Even more, the levels established for acceptance strongly contribute to the analysis of uncertainties (BIPM, 2008) associated with the regionalization of anthromes, allowing the understanding of distortions associated with it (Parreira et al., 2019). Thus, it appears that the standardization of images as a quality control resource (Brewer et al., 2019; ISO, 2015) strongly supports the pillar of reliability (VIM, 2012) of the geospatial data (Sené et al., 2017). Also, through it, an important feature is identified for the comparability (VIM, 2012) of information at the national level (Magliocca et al., 2015). In addition, the traceability (VIM), 2012) of geographic information becomes a mechanism that can be established, since the recognition of characteristics associated with the measurement is expressed along with geospatial data (Bigdeli et al., 2018; BIPM, 2017; Magliocca et al., 2015; Sun et al., 2017)

\section{Use of calibrated alternative instrumentation to provide traceable results}

it is assumed for this tool (ISO, 2017) the use of statistical resources to estimate the population, to enable the comparison of demographic data nationally and internationally (IBGE, 2018b, 2019a). According to the investigation fulfilled here, the tests made at the SIGPC and at the SIGC and the use of statistical tools for imputation and critical analysis of results (IBGE, 2013b) are strong indications of the use of alternative instrumentation, as these are the instruments that enable the verification the convergence or divergence of the results generated (Brondizio et al., 2016; Ryder et al., 2021; Steffen et al., 2015) by the demographic method. In addition, they contribute to the traceability of geographic information, as the variability around the reference value (Landrum et al., 2015; Schug et al., 2018) allows the evaluation of uncertainty and measurement/estimation error (BIPM, 2008). These unique characteristics of the standard method at INDE (IBGE, 2013a) allow for the comparability of geographic information on a national scale, providing a better understanding of the relationship between the different anthromes (Burgess, 2021; Chuai \& Feng, 2019; Do Valle Júnior et al., 2019; Elez et al., 2013; Olsson et al., 2019), which is recommended for structuring the models at a local scale. In this manner, the notes made through this tool (ISO, 2017) 
demonstrate that the demographic data indexed in INDE (CINDE, 2010) bring properties that allow the parity of results in different Brazilian locations, enabling its use in the cluster analysis to meet local demands (Mittaz et al., 2019; Sun et al., 2017).

Tangent to the method of land use and cover (IBGE, 2013a), the tool deals with the use of other imaging sources in the processing and classification software, to analyze its response to these other sources (Dandois \& Ellis, 2013; Mairota et al., 2013; Zahawi et al., 2015). It is worth noting that this tool directly considers the acceptance standard in the evaluation of the results generated (IBGE, 2013a). The verification of the method indicated to the use of other imaging sources for SPRING calibration, where factors such as uncertainties and errors in the products are analyzed when using sources other than Landsat8 (IBGE, 2013a, 2017, 2018a, 2020a). This examination helps to demonstrate the accuracy with which the method operates, indicating weak points that allow the improvement of software (Morrison et al., 2021; Novelli et al., 2016; Saah et al., 2020). Through this metrological tool (ISO, 2017) it was possible to verify the operability of the method, recognizing its ability to produce results by varying the imaging sources (IBGE, 2013a). In addition, it allowed to demonstrate the efficiency of the method when using a given source, showing better results (Bandaru et al., 2013; Tao et al., 2021; Vuolo et al., 2015). Therefore, this is a substantial tool for determining the method's imaging source and directly assists in attesting to the quality intended in the regionalization of anthromes (Roberts et al., 2021; Sené et al., 2017).

\section{Functional checks of measuring and testing equipment}

this feature concerns the temporal analysis of instruments used in operations. The verification made indicated that the historical series of national demographic censuses enabled the improvement of the questionnaire model used (IBGE, 2011, $2013 b, 2020 b)$. This adapted to the new demands of civil society and government, being increased over the years (IBGE, 2013b). Furthermore, the SIGPC and, mainly, the SIGC are indispensable resources for running the checks (ISO, 2017; IBGE, $2013 b)$. They are the indicators of what and how it is produced (ISO, 2017), enabling the operator to review information that does not fit the results acceptance profile (ISO, 2015a, 2015b, 2015c), ensuring the quality of geospatial data. Either with the improvement of the information collection tool, or with the monitoring during the construction of the census data (IBGE, 2013b), resources are obtained that help to reduce errors and uncertainties in the data (BIPM, 2008), which also it is indicated as a resource to guarantee the quality of the mappings of anthromes (Amici, 2011; Ellis, 2013b; Magliocca \& Ellis, 2013; Zheng et al., 2014). In addition, this tool demonstrates how baseline data for cluster analysis evolve (Haines-Young et al., 2012), broadening the understanding of areas and providing more concise demographic data for the regionalization of anthromes (Chetcuti et al., 2021; Erb et al., 2017; Maestripieri et al., 2017; Picuno et al., 2019; Shumba et al., 2021). It is also through the verification of this tool that it is possible to adapt the generated models to new social demands (De Keersmaeker et al., 2014; Jia et al., 2019; Piquer-Rodríguez et al., 2021; Saah et al., 2020), therefore, expanding the scope of the methods may allow, in the future, an expansion of the application of anthromes in land use planning (Keck, 2021; Mbaru et al., 2021; Schaffartzik et al., 2021).

Sdditively, in the land use and cover method (IBGE, 2013a), this metrological tool involves resources for monitoring the processing and classification of orbital images, executed over the time of software use (IBGE, 2017, 2018a, 2020a). It was found in the structure of the standard method (IBGE, 2013a) that these checks are performed based on the minimum accuracy level of acceptance of results (Beskow et al., 2009; Dandois \& Ellis, 2013; Zahawi et al., 2015). Checks are commonly performed during the production of geographic information on land use and cover (Mishra et al., 2021; Wang et al., 2019; Wen et al., 2019). In addition, they are efficient indicators of quality of results, as they allow real-time monitoring of the results generated by the method (Bandaru et al., 2013; Haines-Young et al., 2012; Lark et al., 2017; Maes et al., 2013). Furthermore, when considering this tool normalized in the production of results (ISO, 2017), producers manifest attributes of the results that relate to the reliability of the geospatial data (Ellis \& Wang, 2006; Magliocca et al., 2015; Sené et al.., 2017). Completely, the indications about the origin and operability of the method that generated that information collaborate to guarantee the quality that is expected from the data. Consequently, this tool allows the demonstration of the method's efficiency in producing results within the acceptance standard, ensuring the quality of information for application in cluster analysis (Chuai \& Feng, 2019; Costenbader, 2011; Tao et al., 2021; Vuolo et al., 2015).

\section{Use of checking patterns or work patterns with control charts, when applicable}

Page 20/39 
this tool reflects the use of population projection data to control the information generated during the execution of the method, to fit it into the established acceptance standard (population projection) (IBGE, 2018b, 2019a). The SIGPC and the SIGC enable the use of this standard in the control of information, as they indicate differences between the expected and obtained results, through quality indicators (IBGE, 2011, 2013b). This enables correction and continuous improvement actions in the method (ISO, 2015a, 2015b, 2015c; Mahmoud et al., 2021), which is essential to adjust it to variations in different locations (IBGE, 2013b). In this way, the continuous control of the production of results helps in the characterization of the data (Koch et al., 2021; Mbaru et al., 2021; Peng et al., 2021). This verification provides indications that enable comparability of information (Magliocca et al., 2015; Sené et al., 2017), as it analyzes the uncertainties of measurements/estimations (Arlé et al., 2021; Mittaz et al., 2019; Parreira et al., 2019) characteristic of demographic results (IBGE, 2013b). In addition, this attribute is also associated with the reliability of census information (Ellis \& Wang, 2006; Magliocca et al., 2015). Therefore, by understanding the relationship of this tool $(I S O, 2017)$ with the structuring of the data, there are subsidies to attest to the quality of geographic information, considering method quality indicators (Arlé et al., 2021; Gao et al., 2018; Margulies et al., 2016). Consequently, the application of these geospatial data in the cluster analysis points to the reduction of variations at different scales, minimizing distortions between the different areas that make up the anthromes mapping (Dandois \& Ellis, 2013; Mairota et al., 2013; Okujeni et al., 2018).

In the method of land use and cover (IBGE, 2013a), the tool covers the use of standardization or technical structures to communicate the results generated (IPCC, 2014; Jia et al., 2019). The examination made in the standard method (IBGE, 2013a) pointed to the use of national standardization as a metadata reporting structure (CONCAR, 2017), which is based on the ISO 19115 Standard (ISO, 2003). Normalization (CONCAR, 2017), as a standard, helps in the characterization of properties that enable the comparability of data and metadata from different areas analyzed (Margulies et al., 2016; Sun et al., 2017; van Wilgen, 2021). In this way, it can be assumed that through the reporting structure of INDE (CONCAR, 2017) it is possible to compare data on a national scale, as well as the identification of inconsistencies that can affect the regionalization of anthromes (IBGE, 2013a, 2017, 2018a, 2020a). Furthermore, the use of standardization (CONCAR, 2017) expands the knowledge of geospatial data, enabling the critical analysis of results based on common characteristics between the geographic information produced (Sené et al., 2017; ISO, 2003). Consequently, the broad understanding of the input data in the cluster analysis assumes properties that contributed to improving the results obtained (Feranec et al., 2010; Haines-Young et al., 2012; Landrum et al., 2015; Piquer-Rodríguez et al., 2015), providing greater complexity to the understanding of the mappings generated for the anthromes (Bagstad et al., 2013a; Zahawi et al., 2015).

\section{Intermediate checks on measuring equipment}

these are resources that enable the use of standards as quality indicators (ISO, 2017, 2015). As indicated in this research, the Brazilian census method (IBGE, 2013b), through the SIGPC and SIGC, has resources available that enable the monitoring of the operation, pointing out inconsistencies or errors during data collection (Dandois et al., 2015b). In this way, the control performed during the operation (ISO, 2015b, 2015c) gives robustness to the generated data, leading to the construction of even more reliable geographic information (Goldbergs et al., 2018; Schug et al., 2018). The reliability of the information is extremely important to ensure a better structuring of the model (Sené et al., 2017) of anthromes. Consequently, by assimilating factors such as uncertainty and measurement/estimation error (BIPM, 2008) in the input data of the cluster analysis, strong indications are obtained to improve the mapping of anthromes locally (Parreira et al., 2019). These are the elements that help to delimit how close that mapped data is to reality, thus expanding the understanding of the anthromes model (Blasiak et al., 2021; Blundo et al., 2021; Ozkaynak et al., 2021). In this manner, the use of this tool (ISO, 2017) during the execution of the method expands the possibility of controlling the errors and uncertainties of measurement/estimation (BIPM, 2008), leading to significant improvements in the mapping of anthromes (Ellis, 2015; Morrison et al., 2021).

In the use and cover method (IBGE, 2013a), the tool (ISO, 2017) comprises the assessment of the classification of the result generated by the classification software in the acceptance profile throughout its operation (Brondizio et al., 2016). Minimum precision, confusion matrix (noise) and acceptance threshold (Macarthur \& von Holst, 2012; Magnusson, 2014) are factors that are part of the structure of this tool (ISO, 2017), as demonstrated by the research performed in the standard method (IBGE, 2013a). These three aspects are commonly analyzed and help in the assessment of processing and classification methods 
(Bayoudh et al., 2015; Laraby \& Schott, 2018; Meng et al., 2017). In addition to being important for the quality control of the data generated, the use of this tool directly helps to improve the method of land use and cover and the classification instrument (software) (Roberts et al., 2021; Sené et al., 2017). Furthermore, by establishing the minimum precision of the standard method (Dandois \& Ellis, 2013) and analyzing the acceptance threshold and the confusion matrix (Chetcuti et al., 2021; RamírezDelgado et al., 2021), it was possible to establish the area of $1 \mathrm{~km}^{2}$ as the method's boundary area (IBGE, 2013a). This critical study of the method gives consistency to the information generated, ensuring the quality expected of geospatial information (ISO, 2015b, 2015c). Therefore, investigations linked to this tool (ISO, 2017) add value to the input data in the cluster analysis and assimilate factors that may reflect uncertainty in the mapping of anthromes at a local scale (Goldbergs et al., 2018; Parreira et al., al., 2019).

\section{Replicated tests or calibrations, using the same methods or different methods}

this resource deals directly with the testing of demographic methods (IBGE, 2013b), to infer on their adequacy in the production of population information (ISO, 2017). Reasoning about this aspect, it was observed through this research that the Brazilian census method undergoes several tests before the operation is executed (IBGE, 2013b), a characteristic that is raised as a tool to ensure the efficiency of the method (Bandaru et al., 2013). In addition, the same collection tool (measurement instrument) is used in other operations carried out by the Brazilian Institute of Geography and Statistics, such as the Population Count and the Agricultural Census (IBGE, 2011, 2013b, 2019b, 2020b). These serve as tests for conducting the Demographic Census and help adapt the method to its scope (Magnusson, 2014; Thompson et al., 2002). This practice adds value to the method, expands its understanding and provides consistency to the data generated by it (Macarthur \& von Holst, 2012; Sené et al., 2017). In addition, this tool directly helps to improve the methods and their results (Kashwan \& Holahan, 2014; Magliocca et al., 2014). With this, the application of this tool $(I S O, 2017)$ in the method adds value to the input data, since the testing of the method demonstrates its effectiveness in producing demographic data that meet the acceptance standard established by the producer (Liu et al., 2018; Magnusson, 2014). Therefore, there are good indications for applying the data in the cluster analysis, as the method control is considered in its evaluation (Goldbergs et al., 2018; Schug et al., 2018).

Regarding the method of land use and cover (IBGE, 2013a), the tool (ISO, 2017) portrays the use of standard images in the classification software as a resource for checking the operability of the method against the result acceptance profile (ISO, 2015). As previously presented, standard images take on their own character (Novelli et al., 2016; Pouliot et al., 2014), as they indicate important factors such as error and uncertainty (BIPM, 2008; VIM, 2012) of the product that is generated from it (Parreira et al., 2019). In addition, field ratification, verified in the examination performed using the standard method (IBGE, 2012, 2013a), is another resource that serves as a parallel to the replicated tests (Valle Júnior et al., 2019; Feilhauer \& Schmidtlein, 2011). The ratification or field validation of the result produced by the software helps to correct errors in processing and classification or in their confirmation (Leinenkugel et al., 2013). In view of this, the treatment accomplished by this tool aims to validate results produced (ISO, 2017) through the reassessment of the same sector (Blundo et al., 2021; Mastrandrea et al., 2010; Nunes et al., 2021). Therefore, when using this tool in evaluating the results generated (ISO, 2017), the producer validates his land use and cover data based on concrete evidence (Mbaru et al., 2021; Morrison et al., 2021; Ozkaynak et al., 2021). Consequently, particularities that attest to the reliability of the information are obtained (Caldararu et al., 2021; Ellis, 2014b; van Wilgen, 2021). In this manner, it was proven that these practices are part of the analysis of the results of the method, which contributes to ensuring the quality of the data generated by the producer (Bigdeli et al., 2018; Roberts et al., 2021; Schmidt et al., 2021; Sené et al., 2017). Furthermore, the recommendation to ensure the quality of input data in the cluster analysis to obtain better performance in the regionalization of anthromes finds interesting indications (Dandois et al., 2017; Katila et al., 2014).

\section{Retesting or recalibration of retained items}

these resources $(I S O, 2017)$ refer directly to inconsistencies in the information generated by census methods, pointing to a new measurement/estimation in each census sector (IBGE, 2013b). Through this work in the standard method (IBGE, 2013b), it was noted that the monitoring systems, SIGPC and SIGC, enable the identification of errors or uncertainties (BIPM, 2008; VIM, 2012) in the collections. Through the information indicated by these resources, a new census should be realized (Dandois et al., 
$2015 b)$. In this way, there is a strong correlation between the metrological precept $($ ISO, 2017) and the quality control employed by the National Institute. By controlling inconsistencies through systems (IBGE, 2013b) there is a direct help to the precision and accuracy of information (Magnusson, 2014; Thompson et al., 2002). In addition, the retest (ISO, 2017) offers indications that point to improvement of the methods (Macarthur \& von Holst, 2012). Furthermore, recognizing the implication of this tool (ISO, 2017) in the structure of the demographic method (IBGE, 2013b) contributes to the reliability of the input data, giving consistency to the mappings generated at a local scale (Dandois et al., 2017; Roberts et al., 2021).

In the method of land use and cover (IBGE, 2013a), the tool (ISO, 2017) refers to the re-evaluation of products that do not fit the acceptance profile (minimum precision) in the classification performed by the software (Liu et al., 2018; Mahmoud et al., 2021). At this point, one should also assume the treatment of noise and trend (Magnusson, 2014; Thompson et al., 2002), presented in method validation, which points to the imprecision in the reading made by the computer program (Bayoudh et al., 2015; Pouliot et al., 2014; Saah et al., 2020). Examination of the method revealed that this tool applies to reclassification of orbital images or field validation (IBGE, 2012, 2013a). Both resources are used to fit the classification into the established acceptance profile, correcting inaccuracies in the generated products (Amici, 2011; Leinenkugel et al., 2013). This concern with the result reflects in its reliability, as it demonstrates the accuracy with which the data are handled by the producer (Dandois et al., 2015b; Mittaz et al., 2019). Therefore, through the inferences indicated by this tool in the standard method (IBGE, 2013a), it was possible to identify that the treatments indicated are part of the methodology to produce land use and cover data, providing traits that ensure the quality of geographic information (Arlé et al., 2021; Margulies et al., 2016; Zahawi et al., 2015). Through it, it was noted that these practices expand the knowledge of the area investigated, as they allow the recognition and/or identification of

natural clippings that were not read by the software, which is expressed as a limiting factor in the regionalization of anthromes (Danielsen et al., 2021; Jia et al., 2019; Lark et al., 2017; Shumba et al., 2021; Yang et al., 2019). In this manner, this tool (ISO, 2017) also adds value to the input data in the cluster analysis, leading it to assimilate characteristics that enable approximation with the regional context of the areas (Dandois et al., 2017; Umunay, 2016; Mairota et al., 2013; Parente et al., 2019).

\section{Correlation of results of different characteristics of the same item}

depicts the interpolation of different characteristics present in the census population (ISO, 2017), which are probed through a single measurement/estimation instrument (Dijke et al., 2021; Rosan et al., 2021). In this research on the standard method (IBGE, 2013b) the sample and universe questionnaires were listed as a tool that connects various demographic information. By checking different attributes of the same object, it is possible to identify factors that may be critical or of interest to the development of public policies at a regional or local scale (Dandois et al., 2017; Dandois et al., 2015b; Do Valle Júnior et al., 2019; Landrum et al., 2015; O'Connor et al., 2021). In this sense, it is these data that enable adjustments to the local scale for anthromes (Ellis, 2011; Ellis, 2015). Furthermore, through different characteristics, the range of input data is expanded (Bagstad et al., 2013b), allowing for more complex constructions to understand anthropogenic and environmental dynamics in anthromes (Fuentealba et al., 2021; Gaüzère \& Devictor, 2021; Winkler et al., 2021), as its application in land use planning (Chetcuti et al., 2021; Shumba et al., 2021). In this manner, the implication of this tool $($ ISO, 2017) in the method structure concerns the multiplicity of data applications and provides consistency to the input data.

Regarding the method of land use and cover (IBGE, 2013a), the tool (ISO, 2017) reflects the analysis of different land properties, enabling the classification of different land uses and cover and the identification of cutouts natural, such as watersheds (Haines-Young et al., 2012; Piquer-Rodríguez et al., 2021; Winkler et al., 2021). This tool (ISO, 2017) reflects a basic principle of ecosystem studies: recognizing different characteristics of the same research object (Balthazar et al., 2015; López-Santiago et al., 2014; Olsson et al., 2019; Wang et al., 2019). In this sense, through this tool (ISO, 2017) it was possible to verify whether the standard method (IBGE, 2013a) can identify relevant features in the field, enabling a better understanding of the investigated areas (Magioli et al., 2021a; Vilar \& Joyeux, 2021). According to the examination fulfilled here, it was identified that within the standard of acceptance of results (minimum precision), the method can recognize particulars that identify natural features (Burgess, 2021; Massetti \& Gil, 2020; Picuno et al., 2019), which improves the information in smaller areas (Liu et al., 2018; Saah et al., 2020), as recommended for regionalizing anthromes. Then, the area of $1 \mathrm{~km}^{2}$ significantly reduces the coverage of the land use and cover data (Dandois et al., 2017; Pouliot et al., 2014), enabling its application in the cluster analysis for bring 
the mapping of anthromes closer to the local reality (Danielsen et al., 2021; Didoné et al., 2017; Fuentealba et al., 2021; Yang et al., 2019). In addition, through the analysis of this tool $(I S O, 2017)$ it is possible to attest that the results generated even assimilate the natural contours associated with the areas (IBGE, 2013a), allowing the prospection of anthromes as a resource for land use planning (Chetcuti et al., 2021; Erb et al., 2017; Shumba et al., 2021).

Critical analysis of reported results: this metrological resource (ISO, 2017) reflects the analysis performed after the production of the results, to validate them or not. The investigation in the demographic method (IBGE, 2013b) showed that this tool is already part of the operation, while the information produced is compared with the projected values (IBGE, 2018, 2019a, 2020b). Two characteristics, discussed above, are of paramount importance for critical analysis (ISO, 2015b, 2015c): the standard deviation and the coefficient of variation. These attributes together allow the comparability of generated and projected results (Magliocca et al., 2015; Sené et al., 2017), enabling the assessment of uncertainties associated with measurement/estimation (BIPM, 2008). In addition, they also support the comparison of information used to construct socio-ecological systems from different areas (Jia et al., 2019; López-Santiago et al., 2014; Piquer-Rodríguez et al., 2021; Schaffartzik et al., 2021). Therefore, both statistical tools contribute to solving problems associated with comparability within the country, as the values indicated by them provide opportunities for statistical adjustments to minimize errors in the mappings, allowing them to be approximated to local scales (Hegerl et al., 2010; Mastrandrea et al., 2010; Seebens et al., 2021; Ozkaynak et al., 2021).

On the other hand, in the method of land use and cover (IBGE, 2013a), it portrays the verification of results through preestablished criteria, to accept or refute them (ISO, 2017). This procedure, characteristic of Management Systems (ISO, 2015b, 2015c), is assimilated as an indispensable resource in the production of geospatial data $($ ISO, 2003) and integrates the methodological framework for evaluating the results (IBGE, 2013a, 2017, 2018a, 2020a). This tool is essential for managing and ensuring the quality of the data generated (ISO, 2015b, 2015c, 2017) and provides evidence that supports the reliability of geographic information (Sené et al., 2017). The examination fulfilled in the standard method (IBGE, 2013a) showed that this Standard tool $(I S O, 2017)$ permeates the entire production process of land use and cover data, from the cabinet stage to the final mapping. So, by employing this mechanism (ISO, 2017) in the evaluation of results, the official producer reveals attributes that guarantee the quality of information and that demonstrate the adequacy of the methods in providing results that meet the standard established by the producer (Valle Júnior et al., 2019; Laraby \& Schott, 2018; Magnusson, 2014; Meng et al., 2017). Consequently, reliability integrates value to land use and cover data (Sené et al., 2017), corroborating the application of these data in the cluster analysis (Haines-Young et al., 2012; Wang \& Han, 2019).

\section{Intralaboratory comparisons}

this feature of the standard (ISO, 2017) depicts the comparison of data generated in different collection units by a responsible data-producing institution (IBGE, 2013b). In the research produced here, this tool (ISO, 2017) is exemplified in the collection points of the units (IBGE, 2013b). In these locations, census data are collected, evaluated, and centralized (IBGE, 2013b). These posts are systemically associated with the central nucleus of the Brazilian Institute of Geography and Statistics (IBGE, 2013b), creating an unbroken chain of information (BIPM, 2017). The Central Nucleus compares the results of the collection points (IBGE, 2013b), which parallels this standardized tool (ISO, 2017; Mahmoud et al., 2021). Through this characterization it is possible to analyze the contribution of this tool to the structuring of the method. By centralizing the information and comparing the results generated in the different units (Amici, 2011; Castillo et al., 2021), the IBGE establishes an important quality control mechanism (Roberts et al., 2021; Thompson et al., 2002), which expresses itself through the criticism and imputation of results (ISO, 2015b, 2015c; Schaffartzik et al., 2021). This mechanism allows the evaluation of the performance of methods (Bayoudh et al., 2015; Magnusson, 2014) in different census structures, as it facilitates the comparability of geospatial data (Sené et al., 2017). This enables a synergy between the results at different levels of aggregation and increases knowledge about the population (Nowosad et al., 2019). This favors a better adjustment of the anthromes mappings to local scales (Okujeni et al., 2018; Plowright et al., 2017; Rial et al., 2017), as the data can be aggregated without compromising its consistency

(Christianson \& Eggleston, 2021; Pouliot et al., 2014), which is necessary for the regionalization of anthropogenic biomes (Ellis, 2011; Ellis, 2015). 
In the method of use and cover (IBGE, 2013a), the tool (ISO, 2017) portrays the comparison of results obtained by the same software in different areas or in stipulated time intervals, taking as a reference the minimum accuracy of acceptance. The tool (ISO, 2017) points to that comparison should performed internally in the laboratory, that is, a single producer comparing results between different areas (Begehold et al., 2016; Dong et al., 2021; Novelli et al., 2016; H. Wang et al., 2019). One can also consider the confrontation between data for the same area at different imaging periods (Balvanera et al., 2017; Calvin et al., 2019; Mittaz et al., 2019; Schmidt et al., 2021). In the examination fulfilled in the standard method (IBGE, 2013a) it was found that this tool (ISO, 2017) is applied to evaluate the imaging sources to be applied in the standard method. This procedure is efficient for the qualitative assessment of orbital image sources, as it allows the identification of particularities that improve the performance of the processing and classification software (IPCC, 2014; Mastrandrea et al., 2010). Still, temporal analyzes of areas are of paramount importance to efficiently distinguish changes in land use and cover (Landrum et al., 2015; Meng et al., 2017; Picuno et al., 2019; Seebens et al., 2021). In this sense, the research performed using the standard method (IBGE, 2013a) revealed that this tool (ISO, 2017) is assimilated into the methodological structure, in view of the production of biennial reports on the uses and coverage of areas (IBGE, 2017, 2018a, 2020a). This investigation by the official producer allows the identification of significant changes in the terrain, allowing a better spatialization of geographic information (Grassi et al., 2021; Koch et al., 2021; Winkler et al., 2021; Yletyinen et al., 2021). In addition, the use of this resource (ISO, 2017) in the evaluation of results generated by the standard method (IBGE, 2013a) allows the evaluation of the method's operability, as the indications made for different areas reveal points of inaccuracy (Arlé et al., 2021; Maestripieri et al., 2017; Saah et al., 2020), which can be adjusted, thus improving the results obtained. In this way, the use and cover method (IBGE, 2013a) carries with it evidence that helps to characterize the quality of geospatial information (Elez et al., 2013), contributing to obtain better results in the cluster analysis for regionalization of anthromes nationally (Massetti \& Gil, 2020; Okujeni et al., 2018).

\section{Tests of blind sample(s)}

this is the lack of knowledge of the population or its specific characteristics (ISO, 2017). According to the examination of the census method (IBGE, 2013b), the population, despite being projected, is not known, as well as its attributes. Therefore, the application of this tool (ISO, 2017) directly affects the ability of the demographic method to efficiently recognize and identify these characteristics (Landrum et al., 2015; Mairota et al., 2013; Picuno et al., 2019). When comparing projected data (IBGE, 2018b) to measured/estimated data (IBGE, 2013b, 2019a), there is evidence that allows the verification of the method's ability to produce demographic data (Magnusson, 2014). In addition, through this tool (ISO, 2017) information can be collected that contributes to the identification of characteristics that can improve the mapping of anthromes (Bakker et al., 2021; Ellis, 2014a; Jiao et al., 2010; Magliocca et al., 2013, 2014), so that they meet the demands of public management (Olsson et al., 2019). Consequently, this tool (ISO, 2017) is of great importance for the structuring of the method (IBGE, 2013a), as it is indicating how the methods work within an acceptance standard (Macarthur \& von Holst, 2012), directly supporting the quality of the information produced (Mastrandrea et al., 2010; Roberts et al., 2021; Sené et al., 2017).

Tangent to the method of land use and cover (IBGE, 2013a), the tool (ISO, 2017) covers the processing and classification of orbital images without any treatment or prior knowledge of land use and cover (Bayoudh et al., 2015; Novelli et al., 2016; Yang et al., 2019). As indicating by the investigation fulfilled here in the standard method (IBGE, 2013a), there is no information in the orbital images applied in the software that point to a particular use and/or cover. In this sense, the importance of establishing a minimum precision level for acceptance of the results reveals the method's ability to distinguish the characteristics of terrains (Brondizio et al., 2016; Dandois \& Ellis, 2013; Sené et al., 2017). It is through this level that the uncertainty and error (BIPM, 2008) associated with the processing and classification of orbital images are verified (Amici, 2011; Saah et al., 2020) and the quality is guaranteed of the information produced (Dandois et al., 2017). This examination allowed us to identify that this is a basic precept for the operation of the standard method, since the processed and classified orbital images must fit the acceptance profile to be validated (IBGE, 2013a). Therefore, the use of reference values (ISO, 2015a) in the standard method of INDE (IBGE, 2013a) strongly helps in ensuring the quality of results (ISO, 2015b, 2015c, 2017) indexed on the platform. Furthermore, the results are composed of attributes such as uncertainty and error (VIM, 2012), which provides a better recognition of the areas (Bigdeli et al., 2018; van Wilgen, 2021) and allows for an understanding of how these two factors can distort the regionalization of anthromes (Mahmoud et al., 2021).

Page 25/39 
After reflecting on the tools to ensure the validity of internal results (item 7.7.1.) (ISO, 2017), it is confirmed that these metrological resources also significantly contribute to the critical analysis of results (Brondizio et al., 2016; Ryder et al., 2021) and provide indications on the quality of data (Arlé et al., 2021; Margulies et al., 2016; Sené et al., 2017) indexed in the INDE platform (CINDE, 2010). They provide mechanisms for verification of geospatial data, inferring about the reliability (VIM, 2012) of the geographic information produced (ISO, 2017), supporting users of geospatial data. In addition, they assume a decisionmaking character in the regionalization of Brazilian anthromes, as they portray aspects that concern the comparability (VIM, 2012) of information at different levels of population aggregation (Brutschin et al., 2021). One must also assume the particularities of the results that enable the traceability $(\mathrm{VIM}, 2012)$ of geospatial data, in view of the different scales that the mapping of anthromes must meet (Balvanera et al., 2017; Dandois et al., 2017; Jia et al., 2019; Winkler et al., 2021) for its application as a land use planning tool (Chetcuti et al., 2021; Saah et al., 2020).

\section{Conclusions}

The analytical system proposed in this work allowed the structuring of a critical analysis method to guarantee the quality of demographic results and land use and cover. By articulating the bases of Metrology with Human Ecology methods, attributes of the methods and the results generated by them were identified, which support the pillars of reliability and comparability, and which also enable the structuring of schemes for the traceability of geographic information. Through this investigation, it was understood how each of the items of Norm 17025 are arranged in the methodological structures of the methods of the Brazilian platform and how they are fundamental to add value to the results produced nationally.

Through the method validation parameters, evidence was found that demonstrates the adequacy of the methods to their intended uses and whether they can reduce the coverage areas of geographic information. Complementarily, with the tools to guarantee the validity of internal results, it was verified how the analytical mechanisms used by the institutions that produce spatial data help to guarantee the quality of internal results. Therefore, it was possible to indicate how these metrological tools contribute with users and producers of geospatial data in the critique and imputation of results.

Finally, this critical data analysis provided evidence of the quality of the results indexed in the Brazilian platform, significantly improving the resolution of geographic information and assimilating the natural clippings necessary for adjustment in the national territory. Furthermore, this research points to the application of INDE data in cluster analysis, which will allow the generation of maps of anthromes with metrological reliability for the level of smaller political-administrative regions, such as cities, and for natural areas of socio-ecological importance, such as watersheds and natural parks.

\section{Declarations}

Funding: This study was funded by PRONAMETRO (National Institute of Metrology, Quality and Technology) (Brazil).

Conflicts of interest/competing interests: The authors have no conflicts of interest to declare that are relevant to the content of this article.

Availability of data and material: All data and materials analyzed in this research are available on the platforms of the institutions presented throughout the text (INDE: https://inde.gov.br/; IBGE: https://www.ibge.gov.br/). The electronic addresses for all analyzed documents and sets of metadata are indicated in the tables and are indicated in the bibliography of this work.

Code availability: Not applicable

Authors' contributions: All authors contributed to the study conception and design. Material preparation, data collection and analysis were performed by Maximiliano S. L. A. Gobbo. The first draft of the manuscript was written by Maximiliano S. L. A. Gobbo and all authors commented on previous versions of the manuscript. All authors read and approved the final manuscript.

Ethics approval: Not applicable

Consent to participate: Not applicable

Page 26/39 
Consent for publication: Not applicable

Acknowledgments: Thanks to the "Laboratory for Anthropogenic Landscape Ecology", represented by Professor Dr. Erle C. Ellis, for presenting a set of data and knowledge of paramount importance for establishing the proposal of this work.

\section{References}

1. ALESSA, L., \& CHAPIN, F. S. Anthropogenic biomes: a key contribution to earth-system science. Trends in Ecology \& Evolution, v. 23, n. 10, p. 529-531(2008). ISSN 0169-5347. https://doi.org/10.1016/j.tree.2008.07.002

2. ALTIERI, L., et al. (2014). Urban sprawl scatterplots for Urban Morphological Zones data. Ecological Indicators, v. 36, p. 315-323, ISSN 1470-160X. https://doi.org/10.1016/j.ecolind.2013.07.011

3. ALVARENGA, L. A., et al. (2016). Assessment of land cover change on the hydrology of a Brazilian headwater watershed using the Distributed Hydrology-Soil-Vegetation Model. CATENA, v. 143, p. 7-17, ISSN 0341-8162.

https://doi.org/10.1016/j.catena.2016.04.001

4. AMICl, V. (2011). Dealing with vagueness in complex forest landscapes: A soft classification approach through a nichebased distribution model. Ecological Informatics, v. 6, n. 6, p. 371-383, ISSN 1574-9541.

https://doi.org/10.1016/j.ecoinf.2011.07.001

5. AMIOT, C., et al. (2021). Temporal and sociocultural effects of human colonization on native biodiversity: filtering and rates of adaptation. Oikos, ISSN 0030-1299. https://doi.org/10.1111/oik.07615

6. ARAUJO, T. O., REGO, E. C. P. D., \& AGUIAR, P. F. D. Validação de métodos de medição. In. COSTA-FELIX, R. P. B. e BERNARDES, A. Metrologia - Volume 1: fundamentos. RIO DE JANEIRO: p. 96-116(2017). E-ISBN: 9788574528359

7. ARLÉ, E., et al. (2021). bRacatus: a method to estimate the accuracy and biogeographical status of georeferenced biological data. Methods in Ecology and Evolution. https://doi.org/10.1111/2041-210X.13629ISSN 2041-210X

8. BAGSTAD, K. J., et al. (2013). Spatial dynamics of ecosystem service flows: A comprehensive approach to quantifying actual services. Ecosystem Services, v. 4, p. 117-125, ISSN 2212 - 0416. https://doi.org/10.1016/j.ecoser.2012.07.012 (a)

9. BAGSTAD, K. J., et al. (2013). ; A comparative assessment of decision-support tools for ecosystem services quantification and valuation. Ecosystem Services, v. 5, p. 27-39, ISSN 2212 - 0416. https://doi.org/10.1016/j.ecoser.2013.07.004 (b)

10. BAKKER, V., VERBURG, P. H., \& VAN VLIET, J. (2021). Trade-offs between prosperity and urban land per capita in major world cities. Geography and Sustainability, ISSN 2666-6839. https://doi.org/10.1016/j.geosus.2021.05.004

11. BALTHAZAR, V., et al. (2015). Impacts of forest cover change on ecosystem services in high Andean mountains. Ecological Indicators, v. 48, p. 63-75, ISSN 1470-160X. https://doi.org/10.1016/j.ecolind.2014.07.043

12. BALVANERA, P., et al. (2017). The GEO Handbook on Biodiversity Observation Networks. Cham: Springer International Publishing, p.39-78. ISBN 978-3-319-27288-7. https://doi.org/10.1007/978-3-319-27288-7_3

13. BANDARU, V., et al. (2013). Estimating crop net primary production using national inventory data and MODIS-derived parameters. ISPRS Journal of Photogrammetry and Remote Sensing, v. 80, 61-71.

https://doi.org/10.1016/j.isprsjprs.2013.03.005

14. BATTISTON, S., et al. (2021). Accounting for finance is key for climate mitigation pathways. Science, 10.1126/science.abf3877>

15. BAYOUDH, M., et al. (2015). Structural knowledge learning from maps for supervised land cover/use classification: Application to the monitoring of land cover/use maps in French Guiana. Computers \& Geosciences, v. 76, 31-40. https://doi.org/10.1016/j.cageo.2014.08.013

16. BEGEHOLD, H., RZANNY, M., \& WINTER, S. (2016). Patch patterns of lowland beech forests in a gradient of management intensity. Forest Ecology and Management, v.360, 69-79. https://doi.org/10.1016/j.foreco.2015.10.021

17. BESKOW, S., et al. (2009). Soil erosion prediction in the Grande River Basin, Brazil using distributed modeling. CATENA, v. 79, n. 1, p. 49-59, ISSN 0341-8162. https://doi.org/10.1016/j.catena.2009.05.010

Page 27/39 
18. BIGDELI, B., AMINI AMIRKOLAEE, H., \& PAHLAVANI, P. (2018). DTM extraction under forest canopy using LiDAR data and a modified invasive weed optimization algorithm. Remote Sensing of Environment, v. 216, 289-300.

https://doi.org/10.1016/j.rse.2018.06.045

19. BLASIAK, R., et al. (2021). Evolving Perspectives of Stewardship in the Seafood Industry. Frontiers in Marine Science, v. 8, n. 676ISSN 2296-7745. https://doi.org/10.3389/fmars.2021.671837

20. BLUNDO, C., et al. (2021). Taking the pulse of Earth's tropical forests using networks of highly distributed plots. Biological Conservation, 108849. https://doi.org/10.1016/j.biocon.2020.108849

21. BOER, B. D., et al. (2021). Global environmental and socio-economic impacts of a transition to a circular economy in metal and electrical products. Journal of Industrial Ecology, 1-8. https://doi.org/10.1111/jiec.13133

22. BRASIL. (2008). Infraestrutura Nacional de Dados Espaciais (INDE) - Decreto $n^{\circ}$ 6.666, de 27 de novembro de 2008. BRASÍLIA: PLANALTO CENTRAL

23. BREWER, P. J., et al. (2019). Advances in reference materials and measurement techniques for greenhouse gas atmospheric observations. Metrologia, v. 56, n. 3, p. 034006, ISSN 0026-1394 1681-7575. http://dx.doi.org/10.1088/16817575/ab1506

24. BRONDIZIO, E. S., et al. (2016). Re-conceptualizing the Anthropocene: A call for collaboration. Global Environmental Change, v. 39, p. 318-327, ISSN 0959-3780. https://doi.org/10.1016/j.gloenvcha.2016.02.006

25. BRUTSCHIN, E., et al. (2021). A multidimensional feasibility evaluation of low-carbon scenarios. Environmental Research Letters, v. 16, n. 6, p. 064069, ISSN 1748-9326. http://dx.doi.org/10.1088/1748-9326/abf0ce

26. BUREAU INTERNATIONAL DES POIDS ET MESURES (BIPM). CCQM strategy document for rolling Programme Development. BIPM: BIPM, https://www.bipm.org/documents/20126/2071059/CCQM+Strategy.pdf/31283069-94f4-f2c7bbfc-7d652c9b3de8

27. BUREAU INTERNATIONAL DES POIDS ET MESURES (BIPM). Evaluation of measurement data-Guide to the expression of uncertainty in measurement. Int. Organ. Stand. Geneva ISBN: BIPM, INTERNATIONAL BUREAU OF WEIGHTS AND MEASURES. 50: 134 p. https://www.bipm.org/documents/20126/2071204/JCGM_100_2008_E.pdf/cb0ef43f-baa5-11cf$3 f 85-4 d c d 86 f 77 b d 6$

28. BURKHARD, B., et al. (2012). Mapping ecosystem service supply, demand and budgets. Ecological indicators, v. 21, p. 1729, ISSN 1470-160X. https://doi.org/10.1016/j.ecolind.2011.06.019

29. CALDARARU, S., et al. (2021). Changes in leaf nitrogen and phosphorus content from observations and a land surface model: evidence for increasing nutrient imbalance in Europe. EGU General Assembly 2021: Copernicus Meetings. https://ui.adsabs.harvard.edu/abs/2021EGUGA..23.2912C/abstract

30. CALVIN, K., et al. (2019). Characteristics of human-climate feedbacks differ at different radiative forcing levels. Global and Planetary Change, v. 180, p. 126-135, ISSN 0921-8181. https://doi.org/10.1016/j.gloplacha.2019.06.003

31. CASTILLO, M. L., et al. (2021). The contribution of phenotypic traits, their plasticity, and rapid evolution to invasion success: insights from an extraordinary natural experiment. Ecography, v, 44, 1-16. https://doi.org/10.1111/ecog.05541

32. CHEN, Z., et al. (2021). Linking global terrestrial CO2 fluxes and environmental drivers: inferences from the Orbiting Carbon Observatory 2 satellite and terrestrial biospheric models. Atmospheric Chemistry and Physics, v. 21, 96663-96680. https://dx.doi.org/10.5194/acp-21-6663-2021

33. CHETCUTI, J., KUNIN, W. E., \& BULLOCK, J. M. (2021). Matrix composition mediates effects of habitat fragmentation: a modelling study. Landscape Ecology, 1-16. https://doi.org/10.1007/s10980-021-01243-5

34. CHRISTIANSON, K. A., \& EGGLESTON, D. B. (2021). Testing ecological theories in the Anthropocene: alteration of succession by an invasive marine species. Ecosphere, v, 12, 41-23. https://doi.org/10.1002/ecs2.3471

35. CHUAl, X., \& FENG, J. (2019). ISSN 0048-9697High resolution carbon emissions simulation and spatial heterogeneity analysis based on big data in Nanjing City, China. Science of The Total Environment, v. 686, 828-837.

https://doi.org/10.1016/j.scitotenv.2019.05.138

Page 28/39 
36. COMISSÃO NACIONAL DE CARTOGRAFIA (CONCAR). Norma Cartográfica Brasileira: Especificações Técnicas para Estruturação de Dados Geoespaciais Vetoriais (ET-EDGV 3.0). Brasília: Ministério do Planejamento, Desenvolvimento e Gestão/CONCAR, https://docs.ufpr.br/ deni_ern/CD2020/A1/ET-EDGV_versao_3.0.pdf

37. COMITÊ TÉCNICO PARA IMPLEMENTAÇÃO DA INFRAESTRUTURA NACIONAL DE DADOS ESPACIAIS (CINDE). Plano de Ação para Implantação da Infraestrutura Nacional de Dados Espaciais. RIO DE JANEIRO: Ministério do Planejamento, Orçamento e Gestão, https://www.inde.gov.br/pdf/PlanoDeAcaolNDE.pdf

38. COSTA, G. G. O. Análise de Correlação Canônica das Variáveis Ambientais Internas e Externas que Influenciam na Elaboração do Orçamento das Empresas. Caderno de Administração. Revista da Faculdade de Administração da FEA, v. 11, n. 1(2017). ISSN 2595-4865. https://revistas.pucsp.br/caadm/article/view/28070

39. COSTANZA, R., \& KUBISZEWSKI, I. (2012). The authorship structure of "ecosystem services" as a transdisciplinary field of scholarship. Ecosystem Services, v. 1, n. 1, p. 16-25, ISSN 2212 - 0416. https://doi.org/10.1016/j.ecoser.2012.06.002

40. COSTENBADER, J. (2011). REDD + benefit sharing: a comparative assessment of three national policy approaches. Forest Carbon Partnership Facility and UN REDD Programme

41. CRONA, B., FOLKE, C., \& GALAZ, V. The Anthropocene reality of financial risk. One Earth, v. 4, n. 5, p. 618-628(2021). ISSN 2590-3322. https://doi.org/10.1016/j.oneear.2021.04.016

42. DANDOIS, J. P., et al. (2015). Forest census and map data for two temperate deciduous forest edge woodlot patches in Baltimore, Maryland, USA: Ecological Archives E096-156. Ecology, v. 96, n. 6, p. 1734-1734, ISSN 1939-9170. https://doi.org/10.1890/14-2246.1 (a)

43. DANDOIS, J. P., et al. (2017). What is the point? Evaluating the structure, color, and semantic traits of computer vision point clouds of vegetation. Remote Sensing, v. 9(n. 4), 355. https://doi.org/10.3390/rs9040355

44. DANDOIS, J. P., \& ELLIS, E. C. (2013). ISSN 0034-4257High spatial resolution three-dimensional mapping of vegetation spectral dynamics using computer vision. Remote Sensing of Environment, v. 136, 259-276.

https://doi.org/10.1016/j.rse.2013.04.005

45. DANDOIS, J. P., OLANO, M., \& ELLIS, E. C. (2015). Optimal altitude, overlap, and weather conditions for computer vision UAV estimates of forest structure. Remote Sensing, v. 7, 1013895-1013920. https://doi.org/10.3390/rs71013895 (b)

46. DANIELSEN, F., et al. (2021). The concept, practice, application, and results of locally based monitoring of the environment. BioScience, 1-19. https://doi.org/10.1093/biosci/biab021

47. DE BIEVRE, P., et al. (The Fitness for Purpose of Analytical Methods: A Laboratory Guide to Method Validation and Related Topics. EURACHEM Guide: Eurachem 1998). ISBN: 0-948926-12-0.

48. DE KEERSMAEKER, L., et al. (2014). A spatially explicit empirical model on actual and potential ancient forest plant diversity in a fragmented landscape. Landscape and urban planning, v. 130, p. 149-158, ISSN 0169-2046. https://doi.org/10.1016/j.landurbplan.2014.07.006

49. DEFRIES, R. S., et al. (2012). Planetary opportunities: a social contract for global change science to contribute to a sustainable future. BioScience, v. 62, n. 6, p.603-606, ISSN 1525-3244. https://doi.org/10.1525/bio.2012.62.6.11

50. DELANTY, G. (2018). Os desafios da globalização e a imaginação cosmopolita: as implicações do Antropoceno. Sociedade e Estado, v. 33, n. 2, p. 373-388, ISSN 0102-6992. https://doi.org/10.1590/s0102-699220183302004

51. DIDONÉ, E. J., MINELLA, J. P. G., \& EVRARD, O. (2017). Measuring and modelling soil erosion and sediment yields in a large, cultivated catchment under no-till of Southern Brazil. Soil and Tillage Research, v. 174, 24-33.

https://doi.org/10.1016/j.still.2017.05.011

52. van DIJKE, H., et al. (The 'global tree restoration potential': a first estimation of the hydrological effects. EGU General Assembly 2021). : EGU21-7697 p. 19-30, 2021. https://ui.adsabs.harvard.edu/abs/2021EGUGA..23.7697H/abstract

53. DO VALLE JÚNIOR, R. F., et al. (2019). Diagnosis of degraded pastures using an improved NDVI-based remote sensing approach: An application to the Environmental Protection Area of Uberaba River Basin (Minas Gerais, Brazil). Remote Sensing Applications: Society and Environment, v. 14, p. 20-33, ISSN 2352-9385.

https://doi.org/10.1016/j.rsase.2019.02.001

Page 29/39 
54. DONG, F., et al. (2021). Population genomic, climatic and anthropogenic evidence suggest the role of human forces in endangerment of green peafowl (Pavo muticus). https://doi.org/10.1098/rspb.2021.0073

55. ELEZ, J., et al. (2013). A GIS-based methodology to quantitatively define an Adjacent Protected Area in a shallow karst cavity: The case of Altamira cave. Journal of environmental management, v. 118, 122-134. https://doi.org/10.1016/j.jenvman.2013.01.020

56. ELLIS, E. C., et al. (2010). Anthropogenic transformation of the biomes, 1700 to 2000. Global ecology and biogeography, v. 19, n. 5, p. 589-606, ISSN 1466-822X. https://doi.org/10.1111/j.1466-8238.2010.00540.x

57. ELLIS, E. C., et al. (2013). Dating the Anthropocene: Towards an empirical global history of human transformation of the terrestrial biosphere: Dating the Anthropocene. Elementa: Science of the Anthropocene, v. 1, https://doi.org/10.12952/journal.elementa.000018 (a)

58. ELLIS, E. C., et al. (2006). Measuring long-term ecological changes in densely populated landscapes using current and historical high resolution imagery. Remote Sensing of Environment, v. 100(n. 4), 457-473. https://doi.org/10.1016/j.rse.2005.11.002

59. ELLIS, E. C. A taxonomy of the human biosphere. Projective Ecologies. Actar. Harvard, p. 168-182(2014). https://doi.org/10.1111/j.1466-8238.2010.00540.x (a)

60. ELLIS, E. C. Anthropogenic transformation of the terrestrial biosphere. Philosophical Transactions of the Royal Society A: Mathematical, Physical and Engineering Sciences, v. 369, n(1938). p. 1010-1035, 2011. ISSN 1364-503X. https://doi.org/10.1098/rsta.2010.0331

61. ELLIS, E. C. (2014). ISBN 9781934510377 (b)Ecologies of the Anthropocene: Global Upscaling of Social-Ecological Infrastructures. New Geographies, v. 6, 20-27.

62. ELLIS, E. C. Ecology in an anthropogenic biosphere. Ecological Monographs, v. 85, n. 3, p. 287-331(2015). ISSN 15577015. https://doi.org/10.1890/14-2274.1

63. ELLIS, E. C. Sustaining biodiversity and people in the world's anthropogenic biomes. Current Opinion in Environmental Sustainability, v. 5, n. 3-4, p. 368-372(2013). ISSN 1877-3435. https://doi.org/10.1016/j.cosust.2013.07.002 (b)

64. ELLIS, E. C., ANTILL, E. C., \& KREFT, H. All is not loss: plant biodiversity in the Anthropocene. PlosOne, v. 7, n. 1, p. e30535, 2012. ISSN 1932-6203. https://doi.org/10.1371/journal.pone.0030535

65. ELLIS, E. C., \& RAMANKUTTY, N. (2008). Putting people in the map: anthropogenic biomes of the world. Frontiers in Ecology and the Environment, v. 6, n. 8, p. 439-447, ISSN 1540-9309. https://doi.org/10.1890/070062

66. ELLIS, E., \& WANG, H. (2006). Estimating area errors for fine-scale feature-based ecological mapping. International Journal of Remote Sensing, v. 27, 214731-214749. https://doi.org/10.1080/01431160600735632

67. ERB, K. H., et al. (2017). ISSN 1354 - 1013Land management: data availability and process understanding for global change studies. Global Change Biology, v. 23(n. 2), 512-533. https://doi.org/10.1111/gcb.13443

68. FEILHAUER, H., \& SCHMIDTLEIN, S. On variable relations between vegetation patterns and canopy reflectance. Ecological Informatics, v. 6, n. 2, p. 83-92(2011). ISSN 1574-9541. https://doi.org/10.1016/j.ecoinf.2010.12.004

69. FERANEC, J., et al. (2010). Determining changes and flows in European landscapes 1990-2000 using CORINE land cover data. Applied geography, v. 30(n. 1), 19-35. https://doi.org/10.1016/j.apgeog.2009.07.003

70. FERMAM, R. K. S. O papel da Metrologia no Desenvolvimento Sustentável: o caso das emissões de gases de efeito estufa. Revista Ibero-Americana de Ciências Ambientais, v. 3, n. 2(2012). ISSN 2179-6858.

71. FINLAYSON, C. M., GELL, P. A., \& CONALLIN, J. (2021). Continuing the discussion about ecological futures for the lower Murray River (Australia) in the Anthropocene. Marine and Freshwater Research, ISSN 1448-6059. https://doi.org/10.1071/MF20344

72. FREIRE, A. P., \& CASTRO, E. Análise da Correlação do uso e Ocupação do Solo e da Qualidade da Água. Revista Brasileira de Recursos Hídricos, v. 19, n. 1, p. 41-49(2014). https://abrh.s3.sa-east1.amazonaws.com/Sumarios/161/c720cf8418e55a3f8a9c4280dafd717b_90f8621cd34013b4293a537120beb593.pdf 
73. FUENTEALBA, M., et al. (2021). A window into the Anthropocene through lake-sediment records in central Chile. Past Global Changes, v. 29, n. 1, p.46-47, https://doi.org/10.22498/pages.29.1.46

74. GAO, M., et al. (2018). Air quality and climate change, Topic 3 of the Model Inter-Comparison Study for Asia Phase III (MICS-Asia III)-Part 2: aerosol radiative effects and aerosol feedbacks. Atmospheric Chemistry and Physics, v. 18, 2485924884. https://doi.org/10.5194/acp-18-4859-2018

75. GAÜZÈRE, P., \& DEVICTOR, V. (2021). Mismatches between birds' spatial and temporal dynamics reflect their delayed response to global changes. Oikos, ISSN 0030-1299. https://doi.org/10.1111/oik.08289

76. GIRARDIN, C. A. J., et al. (2021). Nature-based solutions can help cool the planet - if we act now. Nature, v. 593, 78581917858194. https://doi.org/10.1038/d41586-021-01241-2

77. GOLDBERGS, G., et al. (2018). ISSN 0034-4257Hierarchical integration of individual tree and area-based approaches for savanna biomass uncertainty estimation from airborne LiDAR. Remote sensing of environment, v. 205, 141-150. https://doi.org/10.1016/j.rse.2017.11.010

78. GRASSI, G., et al. (2021). Critical adjustment of land mitigation pathways for assessing countries' climate progress. Nature Climate Change, 1-10. https://doi.org/10.1038/s41558-021-01033-6ISSN 1758-67981758-6798

79. GROOT, R. S. D., et al. (2010). The Economics of Ecosystems and Biodiversity (TEEB): Ecological and Economic Foundations. Earthscan, Routledge, p.9-40, ISBN 9781849712125.

80. HAINES-YOUNG, R., POTSCHIN, M., \& KIENAST, F. (2012). Indicators of ecosystem service potential at European scales: mapping marginal changes and trade-offs. Ecological Indicators, v. 21, 39-53.

https://doi.org/10.1016/j.ecolind.2011.09.004ISSN 1470-160X

81. HEGERL, G. C., et al. (2010). Good practice guidance paper on detection and attribution related to anthropogenic climate change. Meeting report of the intergovernmental panel on climate change expert meeting on detection and attribution of anthropogenic climate change: IPCC Working Group I Technical Support Unit. Bern: University of Bernhttps://archive.ipcc.ch/pdf/supporting-material/ipcc_good_practice_guidance_paper_anthropogenic.pdf

82. HOU, E., et al. (2021). Latitudinal patterns of terrestrial phosphorus limitation over the globe. Ecology Letters, v. 24, 7142071431. https://doi.org/10.1111/ele.13761

83. IGBAL, K. M. J., \& KHAN, M. I. (2021). Critical Perspective on Demarking Anthropocene Epoch. PalArch's Journal of Archaeology of Egypt / Egyptology, v. 18(n. 4), 7845-7853ISSN1567-

214xhttps://www.archives.palarch.nl/index.php/jae/article/view/8482

84. INSTITUTO BRASILEIRO DE GEOGRAFIA E ESTATÍSTICA (IBGE). Alteração na Operação de Coleta e Apuração dos Dados In: IBGE, Pesquisa Nacional por Amostras de Domicílios: síntese de indicadores. RIO DE JANEIRO: IBGE, p. 31-32, ISBN 978-85-240-4398-7 https://biblioteca.ibge.gov.br/visualizacao/livros/liv98887.pdf (a)

85. INSTITUTO BRASILEIRO DE GEOGRAFIA E ESTATÍSTICA (IBGE). Base Cartográfica Contínua do Brasil, ao milionésimo documentação técnica geral. RIO DE JANEIRO: IBGE, ISBN: 9788524042171.

https://biblioteca.ibge.gov.br/visualizacao/livros/liv96663.pdf

86. INSTITUTO BRASILEIRO DE GEOGRAFIA E ESTATísTICA (IBGE). Censo Demográfico 2010. https://sidra.ibge.gov.br/pesquisa/censo-demografico/demografico-2010/inicial

87. INSTITUTO BRASILEIRO DE GEOGRAFIA E ESTATÍSTICA (IBGE). Estimativas da população residente para os Municípios e para as Unidades da Federação brasileiros com data de referência em 1º de julho de RIO DE JANEIRO: IBGE, 2019. https://biblioteca.ibge.gov.br/visualizacao/livros/liv101662.pdf (a)

88. INSTITUTO BRASILEIRO DE GEOGRAFIA E ESTATÍSTICA (IBGE). Introdução à Infraestrutura Nacional de Dados Espaciais - INDE: unidade 2 - metadados geoespaciais (curso de capacitação da plataforma INDE). IBGE: IBGE, https://www.inde.gov.br/pdf/capacitacao/Introducao-a-inde-2021-05.pdf (b)

89. INSTITUTO BRASILEIRO DE GEOGRAFIA E ESTATíSTICA (IBGE). Manuais Técnicos em Geociências (n. 12): manual de procedimentos técnicos para fiscalização, controle de qualidade e validação da base cartográfica contínua na escala 1:250000. RIO DE JANEIRO: IBGE, https://biblioteca.ibge.gov.br/visualizacao/livros/liv96663.pdf

Page 31/39 
90. INSTITUTO BRASILEIRO DE GEOGRAFIA E ESTATÍSTICA (IBGE). (2012). Manuais Técnicos em Geociências: manual técnico da vegetação brasileira (2.). RIO DE JANEIRO: IBGE, https://biblioteca.ibge.gov.br/visualizacao/livros/liv63011.pdf

91. INSTITUTO BRASILEIRO DE GEOGRAFIA E ESTATÍSTICA (IBGE). Manuais Técnicos em Geociências: manual técnico de uso da terra. 3. RIO DE JANEIRO: IBGE, https://biblioteca.ibge.gov.br/visualizacao/livros/liv81615.pdf (a)

92. INSTITUTO BRASILEIRO DE GEOGRAFIA E ESTATÍ́STICA (IBGE). Manuais técnicos em Geociências: acesso e uso de dados geoespaciais. RIO DE JANEIRO: IBGE, https://biblioteca.ibge.gov.br/visualizacao/livros/liv101675.pdf (c)

93. INSTITUTO BRASILEIRO DE GEOGRAFIA E ESTATíSTICA (IBGE). Metodologia do censo demográfico 2010. RIO DE JANEIRO: IBGE, ISBN 0101-2843. (b)

94. INSTITUTO BRASILEIRO DE GEOGRAFIA E ESTATÍ́STICA (IBGE). (2017). Monitoramento da Cobertura e Uso da Terra do Brasil 2000-2010-2012-2014 em grade territorial estatística. RIO DE JANEIRO:

IBGEhttps://biblioteca.ibge.gov.br/visualizacao/livros/liv101625.pdf

95. INSTITUTO BRASILEIRO DE GEOGRAFIA E ESTATÍSTICA (IBGE). Monitoramento da Cobertura e Uso da Terra do Brasil 2014-2016. RIO DE JANEIRO: IBGE, https://biblioteca.ibge.gov.br/visualizacao/livros/liv101625.pdf (a)

96. INSTITUTO BRASILEIRO DE GEOGRAFIA E ESTATÍSTICA (IBGE). Monitoramento da Cobertura e Uso da Terra do Brasil 2016-2018. RIO DE JANEIRO: IBGE, https://biblioteca.ibge.gov.br/visualizacao/livros/liv101625.pdf (a)

97. INSTITUTO BRASILEIRO DE GEOGRAFIA E ESTATístICA (IBGE). Pesquisa Nacional por Amostra de Domicílios Contínua: notas técnicas. RIO DE JANEIRO: Ministério da Economia/IBGE,

https://biblioteca.ibge.gov.br/visualizacao/livros/liv101708_notas_tecnicas.pdf (b)

98. INSTITUTO BRASILEIRO DE GEOGRAFIA E ESTATíSTICA (IBGE). Plano Amostral In: IBGE, (Ed.). Pesquisa Nacional por Amostras de Domicilios: síntese de indicadores. RIO DE JANEIRO: IBGE, p. 32-35, ISBN 978-85-240-4398-7 https://biblioteca.ibge.gov.br/visualizacao/livros/liv98887.pdf (b)

99. INSTITUTO BRASILEIRO DE GEOGRAFIA E ESTATíSTICA (IBGE). Principais Alterações Metodológicas, Conceitual e Processual. In: IBGE. Pesquisa Nacional por Amostras de Domicílios: síntese de indicadores. RIO DE JANEIRO: IBGE, p. 2931, ISBN 978-85-240-4398-7 https://biblioteca.ibge.gov.br/visualizacao/livros/liv98887.pdf (c)

100. INSTITUTO BRASILEIRO DE GEOGRAFIA E ESTATÍ́STICA (IBGE). Projeções da população: Brasil e Unidades da Federação - revisão 2018. 2. RIO DE JANEIRO: IBGE, ISBN: 9788524044649 (b)

101. INTERGOVERNMENTAL PANEL ON CLIMATE CHANGE (IPCC). Summary for Policymakers. In: MASSON-DELMOTTE, V.; ZHAl, P., et al (Ed.). Global Warming of $1.5^{\circ} \mathrm{C}$. An IPCC Special Report on the impacts of global warming of $1.5^{\circ} \mathrm{C}$ above preindustrial levels and related global greenhouse gas emission pathways, in the context of strengthening the global response to the threat of climate change, sustainable development, and efforts to eradicate poverty. Geneva, Switzerland:World Meteorological Organization,p.1-32, 2018. https://www.ipcc.ch/sr15/chapter/spm/

102. INTERGOVERNMENTAL PANEL ON CLIMATE CHANGE (IPCC). Summary for policymakers. In: EDENHOFER, O.; PICHSMADRUGA, R., et al (Ed.). Climate change 2014: mitigation of climate change - contribution of Working Group III to the Fifth Assessment Report of the Intergovernmental Panel on Climate Change. Cambridge. Cambridge University Press, p.430, https://www.ipcc.ch/srccl/chapter/summary-for-policymakers/

103. INTERNATIONAL BUREAU OF WEIGHTS AND MEASURES - JOINT COMMITTEE FOR GUIDES IN METROLOGY (BIPM JCGM). International Vocabulary of Metrology (VIM). Metrology. Paris, France: BIPM: 105 p.

https://www.bipm.org/documents/20126/54295284/VIM4_CD_210111b.pdf/0a913bb5-de98-ef12-2031-2b36697997a1

104. INTERNATIONAL ORGANIZATION FOR STANDARDIZATION (ISO). ISO 14001:2015: Environmental management systems Requirements with guidance for use. ISO: ISO/TC 207/SC 1 Environmental management systems: 35 p. ICS: 03.100 .70 Management systems / 13.020.10 Environmental management. (b)

105. INTERNATIONAL ORGANIZATION FOR STANDARDIZATION (ISO). ISO 14004:2016 Environmental management systems General guidelines on implementation. ISO: ISO/TC 207/SC 1 Environmental management systems: 59 p. ICS: 03.100 .70 Management systems / 13.020.10 Environmental management.

106. INTERNATIONAL ORGANIZATION FOR STANDARDIZATION (ISO). ISO 14005:2019 Environmental management systems Guidelines for a flexible approach to phased implementation. ISO: ISO/TC 207/SC 1 Environmental management systems: 
34 p. ICS: 13.020.10 Environmental management.

107. INTERNATIONAL ORGANIZATION FOR STANDARDIZATION (ISO). ISO 19115: Geographic Information - metadata. ISO: ISO/TC 211 Geographic information/Geomatics: 140 p. ICS: 35.240 .70 IT applications in science.

108. INTERNATIONAL ORGANIZATION FOR STANDARDIZATION (ISO). ISO 9001:2015 Quality management systems Requirements. ISO/TC 176/SC 2 Quality systems: ISO: 29 p. 2015. ICS: 03.100.70 Management systems / 03.120.10 Quality management and quality assurance. (c)

109. INTERNATIONAL ORGANIZATION FOR STANDARDIZATION (ISO). ISO GUIDE 31: Reference Materials - contents of certificates, labels and accompanying documentation. ISO/REMCO: ISO/REMCO: 10 p. ICS: 71.040 .30 Chemical reagents (a)

110. INTERNATIONAL ORGANIZATION FOR STANDARDIZATION (ISO). ISO/IEC 17025:2017 General requirements for the competence of testing and calibration laboratories. ISO/CASCO Committee on conformity assessment: ISO/IEC: 30 p. 2017. ICS: 03.120.20 Product and company certification.Conformity assessment.

111. JIA, G., et al. (2019). Climate Change and Land: an IPCC special report on climate change, desertification, land degradation, sustainable land management, food security, and greenhouse gas fluxes in terrestrial ecosystems. IPCC: IPCC, cap. 2, p.131-247, https://www.ipcc.ch/srccl/chapter/chapter-2/

112. JIAO, J., et al. (2010). Distributions of soil phosphorus in China's densely populated village landscapes. Journal of Soils and Sediments, v. 10, n. 3, p. 461-472, ISSN 1439 - 0108. https://doi.org/10.1007/s11368-009-0135-4

113. JUNIOR, H. M. Fractals in Social Sciences: an introductory remark(2021). https://www.academia.edu/47938193/Fractals_in_Social_Sciences_an_introductory_remark

114. KASHWAN, P., \& HOLAHAN, R. (2014). ISSN 1875 - 0281Nested governance for effective REDD+: institutional and political arguments. International Journal of the Commons, v. 8, 554-575. http://doi.org/10.18352/ijc.450

115. KATILA, P., et al. (2014). Forests under pressure: Local responses to global issues. Finland: International Union of Forest Research Organizations (IUFRO), ISBN 978-3-902762-30-6. https://jukuri.luke.fi/bitstream/handle/10024/504504/iufrows32.pdf?sequence=1

116. KECK, M.. Sustainability in agri-food systems: transformative trajectories toward the post-Anthropocene. Sustainability Science, p. 1-3, 2021-04-12 2021. ISSN 1862-4057. https://doi.org/10.1007/s11625-021-00947-6

117. $\mathrm{KOCH}, \mathrm{A}$., et al. (2021). Effects of Earth system feedbacks on the potential mitigation of large-scale tropical forest restoration. Biogeosciences, v. 18, n. 8, p. 2627-2647, ISSN 1726-4170. https://doi.org/10.5194/bg-18-2627-2021

118. LANDRUM, C., et al. (2015). An approach for delineating homogeneous within-field zones using proximal sensing and multivariate geostatistics. Agricultural Water Management, v. 147, 144-153. https://doi.org/10.1016/j.agwat.2014.07.013

119. LARABY, K. G., \& SCHOTT, J. R. (2018). ISSN 0034-4257Uncertainty estimation method and Landsat 7 global validation for the Landsat surface temperature product. Remote Sensing of Environment, v. 216, 472-481.

https://doi.org/10.1016/j.rse.2018.06.026

120. LARK, T. J., et al. (2017). Measuring land-use and land-cover change using the US department of agriculture's cropland data layer: Cautions and recommendations. International journal of applied earth observation and geoinformation, v. 62, 224235. https://doi.org/10.1016/j.jag.2017.06.007

121. LEINENKUGEL, P., et al. (2013). Characterization of land surface phenology and land cover based on moderate resolution satellite data in cloud prone areas-A novel product for the Mekong Basin. Remote sensing of environment, v. 136, p. 180198, ISSN 0034-4257. https://doi.org/10.1016/j.rse.2013.05.004

122. LI, X., et al. (2016). ISSN 2095-9273A cellular automata downscaling based $1 \mathrm{~km}$ global land use datasets (2010-2100). Science Bulletin, v. 61, 211651-211661. https://doi.org/10.1007/s11434-016-1148-1

123. LIU, T., et al. (2018). A fully learnable context-driven object-based model for mapping land cover using multi-view data from unmanned aircraft systems. Remote sensing of environment, v. 216, p. 328-344, ISSN 0034-4257.

https://doi.org/10.1016/j.rse.2018.06.031

Page 33/39 
124. LOFT, L., et al. (2017). Risks to REDD+: potential pitfalls for policy design and implementation. Environmental Conservation, v. 44, n. 01, p. 1-12, ISSN 0376-8929. <>10.1017/S0376892916000412>

125. LOISEAU, N., et al. (2021). Maximizing regional biodiversity requires a mosaic of protection levels. PLOS Biology, v. 19(n. 5), 3001195. https://doi.org/10.1371/journal.pbio.3001195

126. LÓPEZ-SANTIAGO, C. A., et al. (2014). Using visual stimuli to explore the social perceptions of ecosystem services in cultural landscapes: the case of transhumance in Mediterranean Spain. Ecology and Society, v. 19(n. 2), ISSN 1708-3087. http://dx.doi.org/10.5751/ES-06401-190227

127. LOURO, I., et al. (2021). A Sonic Anthropocene. Sound Practices in a Changing Environment. Cadernos de Arte e Antropologia, n. Vol. 10, No 1, p. 3-17, https://doi.org/10.4000/cadernosaa.3377

128. MACARTHUR, R., \& VON HOLST, C. (2012). A protocol for the validation of qualitative methods of detection. Analytical Methods, v. 4, n. 9, p. 2744-2754, <>10.1039/C5AY01822F>

129. MAES, J., et al. (2012). Mapping ecosystem services for policy support and decision making in the European Union. Ecosystem services, v. 1, n. 1, p.31-39, ISSN 2212 - 0416. https://doi.org/10.1016/j.ecoser.2012.06.004

130. MAESTRIPIERI, N., et al. (2017). Dynamic simulation of forest management normative scenarios: the case of timber plantations in the southern Chile. Futures, v. 87, p. 65-77, ISSN 0016-3287. https://doi.org/10.1016/j.futures.2015.10.013

131. MAGIOLI, M., et al. (2021). Land-use changes lead to functional loss of terrestrial mammals in a Neotropical rainforest. Perspectives in Ecology and Conservation, v. 19, n. 2, p. 161-170, ISSN 2530 - 0644.

https://doi.org/10.1016/j.pecon.2021.02.006 (a)

132. MAGIOLI, M., et al. (2021). The role of protected and unprotected forest remnants for mammal conservation in a megadiverse Neotropical hotspot. Biological Conservation, v. 259, p. 109173, ISSN 0006-3207. https://doi.org/10.1016/j.biocon.2021.109173 (b)

133. MAGLIOCCA, N. R., et al. (2015). Synthesis in land change science: methodological patterns, challenges, and guidelines. Regional Environmental Change, v. 15, n. 2, p. 211-226, ISSN 1436-3798. 10.1007/s10113-014-0626-8>

134. MAGLIOCCA, N. R., BROWN, D. G., \& ELLIS, E. C. Cross-site comparison of land-use decision-making and its consequences across land systems with a generalized agent-based model.PLoSOne, v.9, n. 1, p. e86179, 2014. ISSN 1932-6203. https://doi.org/10.1371/journal.pone.0086179

135. MAGLIOCCA, N. R., BROWN, D. G., \& ELLIS, E. C. Exploring agricultural livelihood transitions with an agent-based virtual laboratory: global forces to local decision-making.PloSOne, v. 8, n. 9, p. e73241, 2013. ISSN 1932-6203. https://doi.org/10.1371/journal.pone.0073241

136. MAGLIOCCA, N. R., \& ELLIS, E. C. (2013). Using Pattern-oriented Modeling (POM) to Cope with Uncertainty in Multi-scale Agent-based Models of Land Change. Transactions in GIS, v. 17, 6883-6900. https://doi.org/10.1111/tgis.12012

137. MAGNUSSON, B. The fitness for purpose of analytical methods: a laboratory guide to method validation and related topics. 2. Eurachem(2014). ISBN 9789187461590. http://ri.diva-portal.org/smash/record.jsf?pid=diva2\%3A948751

138. MAHMOUD, G. M., et al. (2021). Proposed approach for force transducers classification. International Journal of Metrology and Quality Engineering, v. 12, 3. https://doi.org/10.1051/ijmqe/2021001

139. MAIROTA, P., et al. (2013). Using landscape structure to develop quantitative baselines for protected area monitoring. Ecological indicators, v. 33, p. 82-95, ISSN 1470-160X. https://doi.org/10.1016/j.ecolind.2012.08.017

140. MARGULIES, J. D., et al. (2016). Ambiguous geographies: connecting case study knowledge with global change science. Annals of the American Association of Geographers, v. 106, n. 3, p. 572-596, ISSN 2469-4452. https://doi.org/10.1080/24694452.2016.1142857

141. MARTíNEZ, A. C., et al.. Earth Observation of Ecosystem Services: CRC Press, v.441, 2013. ISBN: 9780429096563. https://doi.org/10.1201/b15628

142. MAS, J. F., PÉREZ-VEGA, A., \& CLARKE, K. C. (2012). Assessing simulated land use/cover maps using similarity and fragmentation indices. Ecological Complexity, v. 11, 38-45. https://doi.org/10.1016/j.ecocom.2012.01.004ISSN 1476$945 X$ 
143. MASSETTI, A., \& GIL, A. Mapping and assessing land cover/land use and aboveground carbon stocks rapid changes in small oceanic islands' terrestrial ecosystems: A case study of Madeira Island, Portugal (2009-2011). Remote Sensing of Environment, v. 239, p. 111625(2020). ISSN 0034-4257. https://doi.org/10.1016/j.rse.2019.111625

144. MASTRANDREA, M. D., et al. (2010). Guidance note for lead authors of the IPCC fifth assessment report on consistent treatment of uncertainties. Intergovernmental Panel on Climate Change (IPCC). https://archive.ipcc.ch/pdf/supportingmaterial/uncertainty-guidance-note.pdf

145. MATTHEWS, D. (2021). Reframing sovereignty for the Anthropocene. Transnational Legal Theory, p. 1-34, ISSN 20414005. https://doi.org/10.1080/20414005.2021.1929022

146. MBARU, E. K., et al. (2021). Evaluating outcomes of conservation with multidimensional indicators of well-being. Society for Conservation Biology. https://doi.org/10.1111/cobi.13743

147. MENG, R., et al. (2017). Using high spatial resolution satellite imagery to map forest burn severity across spatial scales in a Pine Barrens ecosystem. Remote Sensing of Environment, v. 191, 95-109. https://doi.org/10.1016/j.rse.2017.01.016

148. MISHRA, A., et al. (2021). Estimating global land system impacts of timber plantations using MAgPIE 4.3.2. Geoscientific Model Development, v. p. 1-39, 2021. ISSN 1991-962X. https://doi.org/10.5194/gmd-2021-76

149. MITTAZ, J., MERCHANT, C. J., \& WOOLLIAMS, E. R. Applying principles of metrology to historical Earth observations from satellites. Metrologia, v. 56, n. 3, p. 032002, 2019. ISSN 0026-13941681-7575. http://dx.doi.org/10.1088/16817575/ab1705

150. MORRISON, K. D., et al. (2021). PlosOne, v. 16, 40246662. https://doi.org/10.1371/journal.pone.0246662Mapping past human land use using archaeological data: A new classification for global land use synthesis and data harmonization

151. MOTTL, O., et al. (2021). Global acceleration in rates of vegetation change over the past 18,000 years. Science, v. $372, \mathrm{n}$. 6544 , p. 860, 10.1126/science.abg1685>

152. NEDKOV, S., \& BURKHARD, B. Flood regulating ecosystem services-Mapping supply and demand, in the Etropole municipality, Bulgaria. Ecological Indicators, v. 21, p. 67-79(2012). ISSN 1470-160X.

https://doi.org/10.1016/j.ecolind.2011.06.022

153. NOVELLI, A., et al. (2016). Performance evaluation of object-based greenhouse detection from Sentinel-2 MSI and Landsat 8 OLI data: A case study from Almería (Spain). International journal of applied earth observation and geoinformation, v. 52, 403-411. https://doi.org/10.1016/j.jag.2016.07.011

154. NOWOSAD, J., STEPINSKI, T. F., \& NETZEL, P. (2019). Global assessment and mapping of changes in mesoscale landscapes: 1992-2015. International Journal of Applied Earth Observation and Geoinformation, v. 78, 332-340. https://doi.org/10.1016/j.jag.2018.09.013

155. NUNES, V. F., LOPES, P. M., \& FERREIRA, R. G. Monkeying around Anthropocene: Patterns of human-nonhuman primates' interactions in Brazil. Ethnobiology and Conservation, v. 10, n. 22, p. 1-32(2021). ISSN 2238-4782.

https://doi.org/10.15451/ec2021-04-10.23-1-32

156. O'CONNOR, L. M. J., et al. (2021). Balancing conservation priorities for nature and for people in Europe. Science, v. 372 , n. 6544 , p. 856, 10.1126/science.abc4896>

157. OKUJENI, A., et al. (2018). Generalizing machine learning regression models using multi-site spectral libraries for mapping vegetation-impervious-soil fractions across multiple cities. Remote sensing of environment, v. 216, 482-496. https://doi.org/10.1016/j.rse.2018.07.011

158. OLSSON, L., et al. (2019). Land Degradation. In SKEA, P. R., et al. (Ed.), Climate Change and Land: an IPCC special report on climate change, desertification, land degradation, sustainable land management, food security, and greenhouse gas fluxes in terrestrial ecosystems (pp. 345-436). IPCCSHUKLAhttps://www.ipcc.ch/srccl/chapter/chapter-4/

159. OZKAYNAK, B., RODRIGUEZ-LABAJOS, B., \& ERUS, B. (2021). Understanding activist perceptions of environmental justice success in mining resistance movements. The Extractive Industries and Society.

https://doi.org/10.1016/j.exis.2020.12.008

160. PARENTE, L., et al. (2019). Assessing the pasturelands and livestock dynamics in Brazil, from 1985 to 2017: A novel approach based on high spatial resolution imagery and Google Earth Engine cloud computing. Remote Sensing of

Page $35 / 39$ 
Environment, v. 232, 111301. https://doi.org/10.1016/j.rse.2019.111301

161. PARREIRA, M. R., et al. (2019). Disentangling uncertainties from niche modeling in freshwater ecosystems. Ecological Modelling, v. 391, p. 1-8, ISSN 0304-3800. https://doi.org/10.1016/j.ecolmodel.2018.10.024

162. PEDERSEN, A. F., et al. (2021). Mineral exhaustion and its livelihood implications for artisanal and small-scale miners. Environmental Science and Policy, n. 119, p. 34-43, https://doi.org/10.1016/j.envsci.2021.02.002

163. PENG, W., et al. (7862). Climate policy models need to get real about people - here's how. Nature, v. 594, n. p. 174-176, 2021. https://doi.org/10.1038/d41586-021-01500-2

164. PETRESCU, A. M. R., et al. (2021). The consolidated European synthesis of CO. Earth System Science Data, v. 13, n. 5, p. 2363-2406, ISSN 1866-3508. https://doi.org/10.5194/essd-13-2363-2021

165. PICUNO, P., CILLIS, G., \& STATUTO, D. (2019). Investigating the time evolution of a rural landscape: How historical maps may provide environmental information when processed using a GIS. Ecological Engineering, v. 139, 105580. https://doi.org/10.1016/j.ecoleng.2019.08.010

166. PINTO, D. M., et al. (2020). Tipologias de dados espaciais na Embrapa: uma proposta conceitual para a sua IDE- GEOINFO. In: Simpósio Brasileiro de Infraestrutura de Dados Espaciais. Anais. Rio de Janeiro: IBGE, 2020.: 3 p. http://www.alice.cnptia.embrapa.br/alice/handle/doc/1126851

167. PIQUER-RODRÍGUEZ, M., et al. (2021). Land systems' asymmetries across transnational ecoregions in South America. Sustainability Science, ISSN 1862-4057. https://doi.org/10.1007/s11625-021-00967-2

168. PLOWRIGHT, A. A., et al. (2017). ISSN 0034-4257Multi-scale analysis of relationship between imperviousness and urban tree height using airborne remote sensing. Remote Sensing of Environment, v. 194, 391-400.

https://doi.org/10.1016/j.rse.2017.03.045

169. POULIOT, D., et al. (2014). Development and assessment of a $250 \mathrm{~m}$ spatial resolution MODIS annual land cover time series (2000-2011) for the forest region of Canada derived from change-based updating. Remote Sensing of Environment, v. 140, 731-743. https://doi.org/10.1016/j.rse.2013.10.004

170. QIN, Y., et al. (2021). Carbon loss from forest degradation exceeds that from deforestation in the Brazilian Amazon. Nature Climate Change, 1-7. https://doi.org/10.1038/s41558-021-01026-5ISSN 1758-67981758-6798

171. RAMÍREZ-DELGADO, J., et al. (2021). Matrix condition mitigates the effects of habitat fragmentation on species extinction risk. Nature Portifolio. https://doi.org/10.21203/rs.3.rs-340760/v140p.

172. RIAL, M., CORTIZAS, A. M., \& RODRÍGUEZ-LADO, L. (2017). Understanding the spatial distribution of factors controlling topsoil organic carbon content in European soils. Science of the Total Environment, v. 609, 1411-1422. https://doi.org/10.1016/j.scitotenv.2017.08.012ISSN 0048-9697

173. ROBERTS, J. L., COOPER, W. J., \& LUTHER, D. (2021). Global assessment of forest quality for threatened terrestrial vertebrate species in need of conservation translocation programs. PlosOne, 1-17.

https://doi.org/10.1371/journal.pone.0249378

174. ROCKSTRÖM, J., et al. (7263). A safe operating space for humanity. Nature, v. 461, n. p. 472-475, 2009. ISSN $1476-4687$. https://doi.org/10.1038/461472a

175. RODRÍGUEZ-RODRÍGUEZ, D., SÁNCHEZ-ESPINOSA, A., \& ABDUL MALAK, D. (2021). ISSN 1617 - 1381Potential contribution of OECMs to international area-based conservation targets in a biodiversity rich country, Spain. Journal for Nature Conservation, 126019. https://doi.org/10.1016/j.jnc.2021.126019

176. ROSAN, T. M., et al. (2021). A multi-data assessment of land use and land cover emissions from Brazil during 2000-2019. Environmental Research Letters, 1-14. https://doi.org/10.1088/1748-9326/ac08c3

177. RUSSO, S., et al. (2014). Magnitude of extreme heat waves in present climate and their projection in a warming world. Journal of Geophysical Research: Atmospheres, v. 119, n. 22p. 12, 500-512. https://doi.org/10.1002/2014JD022098ISSN 2169-897X

178. RYDER, S., et al. (2021). Environmental Justice in the Anthropocene. London: Routledge: 358 p. ISBN: 978-0-367-90294-0 (hbk)

Page 36/39 
179. SAAH, D., et al. (2020). Primitives as building blocks for constructing land cover maps. International Journal of Applied Earth Observation and Geoinformation, v. 85, 101979. https://doi.org/10.1016/j.jag.2019.101979

180. SCHAFFARTZIK, A., et al. (2021). The transformation of provisioning systems from an integrated perspective of social metabolism and political economy: a conceptual framework. Sustainability Science, 1-17. https://doi.org/10.1007/s11625-021-00952-9

181. SCHMIDT, N. V., et al. (2021). Assessing impacts of social-ecological diversity on resilience in a wetland coupled human and natural system. Ecology and Society, v. 26, n. 2, <>10.5751/ES-12223-260203>

182. SCHUG, F., et al. (2018). Mapping patterns of urban development in Ouagadougou, Burkina Faso, using machine learning regression modeling with bi-seasonal Landsat time series. Remote Sensing of Environment, v. 210, 217-228. https://doi.org/10.1016/j.rse.2018.03.022

183. SEEBENS, H., et al. (2021). Around the world in 500 years: Inter-regional spread of alien species over recent centuries. Global Ecology and Biogeography, ISSN 1466-822. https://doi.org/10.1111/geb.13325X

184. SENÉ, M., GILMORE, I., \& JANSSEN, J. T. Metrology is key to reproducing results. Nature News, v. 547, n(7664). p. 397-399, 2017. https://doi.org/10.1038/547397a

185. SHUMBA, T., et al. (2021). The influence of biophysical and socio-economic factors on the effectiveness of private land conservation areas in preventing natural land cover loss across South Africa. Global Ecology and Conservation, v. 28, 01670. https://doi.org/10.1016/j.gecco.2021.e01670

186. SOMORIN, O. A., et al. (2014). REDD + policy strategy in Cameroon: Actors, institutions, and governance. Environmental Science \& Policy, v. 35, 87-97. https://doi.org/10.1016/j.envsci.2013.02.004

187. SONG, K., et al. (2012). Wetlands shrinkage, fragmentation and their links to agriculture in the Muleng-Xingkai Plain, China. Journal of environmental management, v. 111, 120-132. https://doi.org/10.1016/j.jenvman.2012.06.038

188. SPALDING, C., \& HULL, P. M. Towards quantifying the mass extinction debt of the Anthropocene. Proceedings of the Royal Society B, 2021-4-28 2021. https://doi.org/10.1098/rspb.2020.2332

189. STEFFEN, W., et al.. Planetary boundaries: Guiding human development on a changing planet. Science, v. 347 , n. 6223 , 2015. ISSN0036-8075.

190. SUN, X. L., et al. (2017). Digital soil mapping based on wavelet decomposed components of environmental covariates. Geoderma, v. 303, p. 118-132, ISSN 0016-7061. https://doi.org/10.1016/j.geoderma.2017.05.017

191. TAO, F., et al. (2021). Process-guided deep learning and Data-driven modelling (PRODA) uncovers key mechanisms underlying global soil carbon storage. 3rd ISMC Conference Advances in Modeling Soil Systems: Copernicus Meetings. https://doi.org/10.5194/ismc2021-10

192. THOMPSON, M., ELLISON, S. L., \& WOOD, R. Harmonized guidelines for single-laboratory validation of methods of analysis (IUPAC Technical Report). Pure and applied chemistry, v. 74, n. 5, p. 835-855(2002). ISSN 1365-3075.

https://doi.org/10.1351/pac200274050835

193. THUM, T., et al. (Using different solutions for radiative transfer of solar-induced fluorescence in a land surface model. EGU General Assembly 2021). : Copernicus Meetings. 2021. https://ui.adsabs.harvard.edu/abs/2021EGUGA..23.8316T/abstract

194. TRAPPES, R. (2021). Defining the Niche for Niche Construction: Evolutionary and Ecological Niches. Forthcoming in Biology and Philosophy, p. 1-17, https://doi.org/10.1007/s10539-021-09805-2

195. UMUNAY, P., et al. (2015). Institutional and Cost-Benefit-Sharing Arrangement for Implementation of Emission Reduction Programme in 12 TAL Districts of Nepal. Kathmandu, Nepal: REDD Implementation Centre, Ministry of Forests and Soil Conservation, Babar Mahal, Kathmandu, Nepal. 137p., http://www.redd.gov.np/upload/e66443e81e8cc9c4fa5c099a1fb1bb87/files/Institutional-and-Cost-Benefit-sharingarrangement-12-tal-districts.pdf

196. UNITED NATIONS (UN). GLOBAL SUSTAINABLE DEVELOPMENT REPORT. USG for Economic and Social Affairs: Bullfrog Powered. $202 \mathrm{p}$.

https://sustainabledevelopment.un.org/content/documents/1758GSDR\%202015\%20Advance\%20Unedited\%20Version.pdf

Page $37 / 39$ 
197. VAN WILGEN, B. W. (2021). ISSN 1022 - 0119Ecology of fire-dependent ecosystems: Wildland fire science, policy and management. African Journal of Range \& Forage Science, 1-2. https://doi.org/10.2989/10220119.2021.1926324

198. VILAR, C. C., \& JOYEUX, J. C. (2021). Brazil's marine protected areas fail to meet global conservation goals. Animal Conservation, ISSN 1367-9430. https://doi.org/10.1111/acv.12703

199. VUOLO, F., et al. (2015). Satellite-based irrigation advisory services: A common tool for different experiences from Europe to Australia. Agricultural water management, v. 147, p. 82-95, ISSN 0378-3774.

https://doi.org/10.1016/j.agwat.2014.08.004

200. WANG, G., \& HAN, Q. (2019). Assessment of the relation between land use and carbon emission in Eindhoven, the Netherlands. Journal of environmental management, v. 247, 413-424. https://doi.org/10.1016/j.jenvman.2019.06.064

201. WANG, H., \& ELLIS, E. C. Image misregistration error in change measurements. Photogrammetric Engineering \& Remote Sensing, v. 71, n. 9, p. 1037-1044(2005). ISSN 0099-1112. https://doi.org/10.14358/PERS.71.9.1037

202. WANG, S., et al. (2019). Temporal-spatial changes about the landscape pattern of water system and their relationship with food and energy in a mega city in China. Ecological Modelling, v. 401, 75-84.

https://doi.org/10.1016/j.ecolmodel.2019.02.010

203. WEISSTEINER, C. J., et al. (2011). Spatial explicit assessment of rural land abandonment in the Mediterranean area. Global and Planetary Change, v. 79, n. 1-2, p. 20-36, ISSN 0921-8181. https://doi.org/10.1016/j.gloplacha.2011.07.009

204. WEN, J., et al. (2019). Spatial heterogeneity of the carbon emission effect resulting from urban expansion among three coastal agglomerations in China. Sustainability, v. 11, 174590. https://doi.org/10.3390/su11174590

205. WINKLER, K., et al.. Global land use changes are four times greater than previously estimated. Nature Communications, v. 12, n. 1, p. 1-10, 2021-05-11 2021. ISSN 2041-17232041-1723. https://doi.org/10.1038/s41467-021-22702-2

206. YANG, L., et al. (2019). Monitoring policy-driven crop area adjustments in northeast China using Landsat-8 imagery. International Journal of Applied Earth Observation and Geoinformation, v. 82, 101892. https://doi.org/10.1016/j.jag.2019.06.002

207. YLETYINEN, J., et al. (2021). Multiple social network influences can generate unexpected environmental outcomes. Scientific Reports, v. 11, n. 1, p. 1-14, ISSN 2045-23222045-2322. https://doi.org/10.1038/s41598-021-89143-1

208. ZAHAWI, R. A., et al. (2015). Using lightweight unmanned aerial vehicles to monitor tropical forest recovery. Biological Conservation, v. 186, p. 287-295, ISSN 0006-3207. https://doi.org/10.1016/j.biocon.2015.03.031

209. ZHENG, B., MYINT, S. W., \& FAN, C. (2014). ISSN 0169-2046Spatial configuration of anthropogenic land cover impacts on urban warming. Landscape and Urban Planning, v. 130, 104-111. https://doi.org/10.1016/j.landurbplan.2014.07.001

\section{Figures}

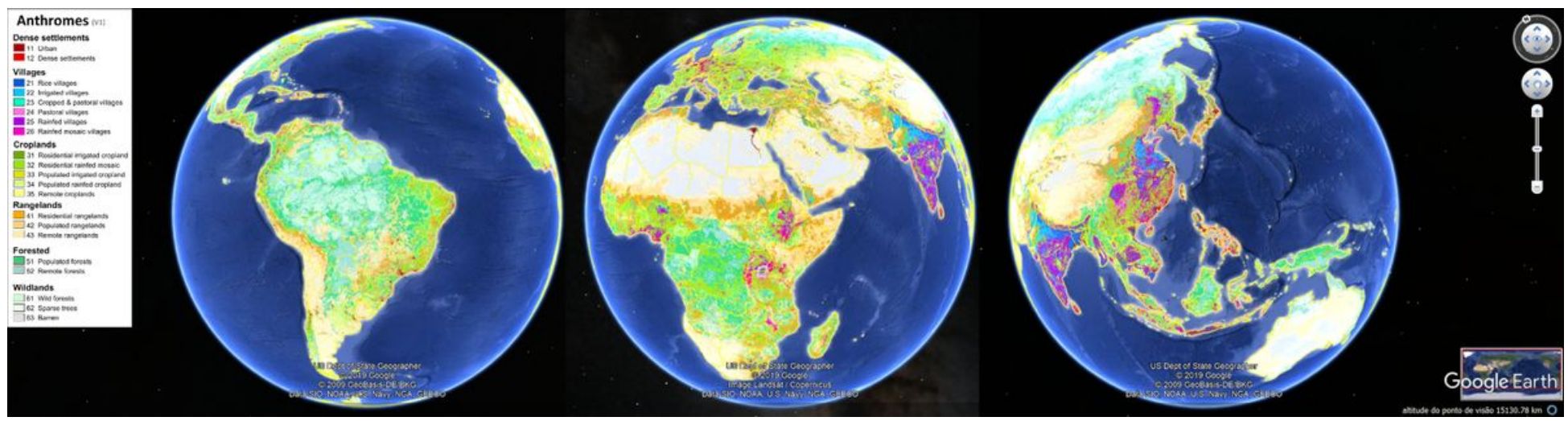

Figure 1

Global Anthromes on Google's Earth platform Source: the author. 
SATELLITE IMAGE

REGION OF THE STATE OF RIO DE JANEIRO

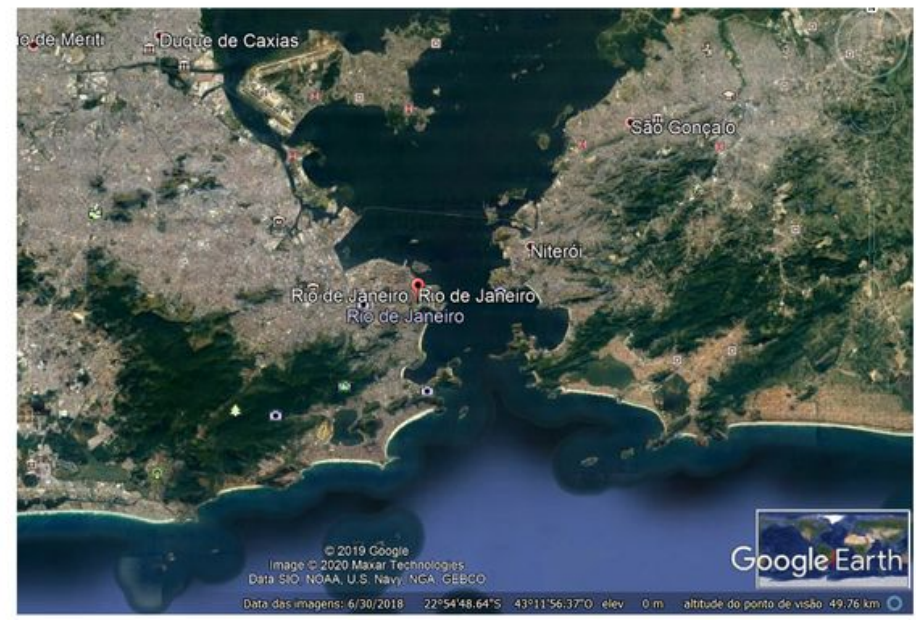

SATELLITE IMAGE WITH ANTROMAS SUPPLEMENT REGION OF THE STATE OF RIO DE JANEIRO

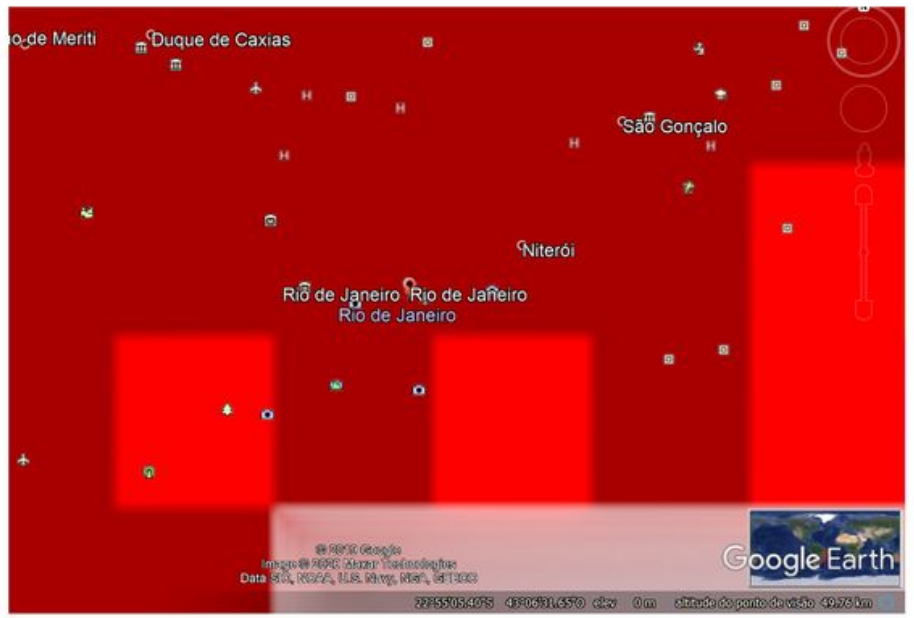

URBAN CENTER

URBAN CENTERS WITH HIGH DEMOGRAPHIC DENSITY

\section{Figure 2}

Comparison between Satellite Image and Satellite Image with anthromes Supplement on the Google Earth Platform. Source: the author. 